\title{
Modeling and Forecasting Electricity Demand in Azerbaijan Using Cointegration Techniques
}

\author{
Fakhri J. Hasanov ${ }^{1,2, *}$, Lester C. Hunt ${ }^{1,3}$ and Ceyhun I. Mikayilov ${ }^{4,5}$ \\ 1 King Abdullah Petroleum Studies and Research Center (KAPSARC), P.O. Box 88550, Riyadh 11672, \\ Saudi Arabia; L.Hunt@surrey.ac.uk \\ 2 Institute of Control Systems, Institute of Cybernetics, B. Vahabzade Street 9, Baku AZ1141, Azerbaijan \\ 3 Surrey Energy Economics Centre (SEEC), University of Surrey, Guildford, Surrey GU2 7XH, UK \\ 4 Department of Economics and Administrative Sciences, Qafqaz University, H. Aliyev Street 120, \\ Khirdalan AZ0101, Azerbaijan; cmikayilov@qu.edu.az \\ 5 Institute for Scientific Research on Economic Reforms, 88a, Hasan Bey Zardabi Avenue, \\ Baku AZ1011, Azerbaijan \\ * Correspondence: Fakhri.Hasanov@kapsarc.org; Tel.: +966-540-900-964
}

Academic Editor: Francisco Martínez-Álvarez

Received: 31 July 2016; Accepted: 21 November 2016; Published: 13 December 2016

\begin{abstract}
Policymakers in developing and transitional economies require sound models to: (i) understand the drivers of rapidly growing energy consumption and (ii) produce forecasts of future energy demand. This paper attempts to model electricity demand in Azerbaijan and provide future forecast scenarios-as far as we are aware this is the first such attempt for Azerbaijan using a comprehensive modelling framework. Electricity consumption increased and decreased considerably in Azerbaijan from 1995 to 2013 (the period used for the empirical analysis) —it increased on average by about $4 \%$ per annum from 1995 to 2006 but decreased by about $4 \frac{1}{2} \%$ per annum from 2006 to 2010 and increased thereafter. It is therefore vital that Azerbaijani planners and policymakers understand what drives electricity demand and be able to forecast how it will grow in order to plan for future power production. However, modeling electricity demand for such a country has many challenges. Azerbaijan is rich in energy resources, consequently GDP is heavily influenced by oil prices; hence, real non-oil GDP is employed as the activity driver in this research (unlike almost all previous aggregate energy demand studies). Moreover, electricity prices are administered rather than market driven. Therefore, different cointegration and error correction techniques are employed to estimate a number of per capita electricity demand models for Azerbaijan, which are used to produce forecast scenarios for up to 2025. The resulting estimated models (in terms of coefficients, etc.) and forecasts of electricity demand for Azerbaijan in 2025 prove to be very similar; with the Business as Usual forecast ranging from about of $19 \frac{1}{2}$ to 21 TWh.
\end{abstract}

Keywords: Azerbaijan electricity demand; time series analysis; cointegration and error correction models; forecast scenarios

\section{Introduction}

Understanding what drives electricity demand and being able to produce sound projections of future demand is increasingly important for both electricity market participants as well as regulators and policy makers. This is particularly true in developing and transitional countries that sometimes experience rapid change over a very short period. This paper attempts to estimate a range of econometric models for per capita electricity demand in Azerbaijan and use them to provide future forecast scenarios for Azerbaijani electricity demand. This is, as far as we are aware, the first to attempt of its kind for Azerbaijan using a comprehensive modelling framework. 
Understanding the growth of electricity demand is crucial for energy producers to manage profits, for policymakers to make better decisions, and governments to manage limited resources for sustainable development. Electricity demand forecasts are important in order to determine a country's electricity "capacity" needs as well as anticipating the prospects of potential excess or likely solutions for possible shortages, particularly in developing and transitional economies. Moreover, the challenges posed by the inability to store electricity in large amounts and the limits of generation capacity, necessitate reliable electricity demand forecasts.

There is a vast literature that attempts to analyze the determinants of electricity demand using a range of techniques and geographical coverage. This includes cross-section and panel data studies for a group of countries and time-series studies for individual countries. On the whole, cross-section and panel data studies assume that the responses to changes in the economic drivers of income and price (i.e., income and price elasticities) are homogenous - with country-specific aspects generally only captured via mechanisms such as fixed and random effects. Such studies are useful (for example, when attempting to measure relative energy efficiency across countries, such as [1]); however, cross-section and panel data studies do not generally "capacity" all the country-specific features of the demand relationship. Therefore, single country-based studies arguably have a key advantage in that they attempt to reveal the "hidden" details of the demand relationship (such as country specific income and price elasticities) for the nations being considered, thus providing a better understanding of the different aspects of energy consuming behavior. Given this, a per capita electricity demand model is built for Azerbaijan and used to produce electricity demand forecast scenarios. Azerbaijan is chosen given its interesting recent history of development since it left the former Soviet Union. The country has experienced very high economic growth, especially in the 2000s. In addition, Azerbaijan is a natural resource rich (oil and gas mainly) small open developing economy that centrally sets its domestic energy prices (rather than leaving to market forces to determine), therefore the strategy and general outcomes of this research could be a guide for other similar economies, such as Kazakhstan, Saudi Arabia and Oman.

The abundance of oil and gas resources is seen as one of the main reasons for Azerbaijan's recent rapid economic growth. Over the period 1995 to 2014 Azerbaijan's per capita real GDP increased from about 3000 US $\$ 2005$ to just under 15,000 US\$2005 [2], which represents an increase of over five times and an average growth of almost $9 \frac{1}{2} \%$ per annum - mainly due to the boom in the oil sector [3]. Furthermore, it is worth noting that according to [4], Azerbaijan is now an upper middle-income country, ranked first in the world in terms of total real GDP growth in 2005, 2006, and 2007 of about $26 \%, 35 \%$, and $25 \%$, respectively.

Moving to electricity consumption, the share of Azerbaijan's electricity use in final energy consumption increased rapidly from 2000, reaching a 19\% share of total energy consumption in 2005. However, from 2006 onwards the level of electricity consumption fell rapidly—in all probability driven by the strong (three times) increase in electricity tariffs in 2007 and the introduction of metering devices [5]. Furthermore, after 2007, there was a tendency for Azerbaijan consumers to switch from electricity to natural gas to fuel in their heating systems [6]. However, electricity consumption in Azerbaijan grew continuously from 2010 onwards [7], which is maybe not surprising given that, according to [8], electricity prices in Azerbaijan were generally lower than in other countries-being administered and set centrally by the government. For instance, the 2010 per MWh electricity prices for households in Korea, Austria, Japan, France, Germany, and the UK were 116.5, 230.8, 182.8, 143.0, 297.2, and 179.8 US\$ (on a purchasing power basis), respectively compared to 75 US\$ in Azerbaijan.

From the supply side, since 2000, Azerbaijan installed electricity production capacity of about 7.3 GW (mainly using natural gas, $85 \%$, but also some hydropower, $15 \%$ ) with electricity production increasing continuously [9]. Thus, Azerbaijan has the potential to take advantage of energy trade with neighboring countries; it exports electricity to Russia, Turkey, and Iran but mainly based on swap conditions [10]. Indeed, before 2000, the country was a net electricity importer but since then it has become a net exporter; for example, according to [10], over $500 \mathrm{GWh}$ was exported in 2012. 
Therefore, the challenge to Azerbaijan policy makers is ensuring that the country meets the domestic demand for electricity but at the same time successfully sells the appropriate amount of electricity to neighboring countries.

Given this background, it is important for Azerbaijani policymakers to have reliable and transparent information on the price and income elasticities of electricity demand, when considering policies related to electricity pricing, optimal taxation, demand forecasting, demand-side management of electricity, and investment in new electricity power production facilities. There is thus scope for a study that estimates robust Azerbaijan electricity demand relationships that captures country-specific aspects, which can be used to produce electricity demand forecast scenarios. A few reports have considered electricity demand forecasts for Azerbaijan such as [11-15]; however, arguably they have a number of drawbacks. Firstly, they used a short data span (for example, [13] used only four-years of data from 2009 to 2012) and did not perform any small sample bias corrections. Secondly, although they used time series data, the issue of non-stationarity was not addressed (that potentially could result in spurious inferences and projections if not dealt with appropriately). Thirdly, the methodologies used are not clearly described in the reports. Finally, it appears that only GDP growth was used as the driver of electricity demand and therefore they potentially suffer from omitted variable bias problems.

Given these perceived problems with the previous reports, the research undertaken here builds models for analyzing and forecasting Azerbaijan per capita electricity demand using different cointegration techniques-system-based, single equation-based as well as residual-based. The data covers the period from 1995 to 2013, which is longer than the data periods is used in the reports discussed above; nonetheless, it should be noted that this is still short by statistical/econometric standards. However, these data are all that are publicly available and usable and thus, despite the relatively short period, allows a useful exercise to be conducted in order to attempt to discover what can be achieved for a country that needs research in this area. Moreover, in order to overcome any potential bias caused by the small sample used, the estimation results include small sample bias corrections. The study therefore contributes to the existing literature in a number of ways. Firstly, as far as is known, this is the first study devoted to the electricity demand modeling and forecasting for Azerbaijan, applying different cointegration methods to time-series data. Secondly, Non-oil GDP is used as a measure of economic activity since overall Azerbaijan GDP is hugely influenced by oil price fluctuations and it is believed that using this would give misleading results. Thirdly, Azerbaijan Heating Degree Days (HDD) and Cooling Degree Days (CDD) variables are considered alongside other explanatory variables in the analysis. Fourthly, considering that there are very few previous academic studies devoted to electricity consumption in Azerbaijan, this study potentially makes a useful contribution to this limited literature. Finally, the research undertaken here can also be considered in other oil and gas rich developing economies that set prices centrally, such as Kazakhstan, Saudi Arabia, and Oman as they have many similarities to Azerbaijan.

In summary, this research attempts to build econometric models for per capita electricity demand in Azerbaijan and use them to produce forecast scenarios for future electricity demand. In doing so, a number of research questions are considered. What is the best cointegration technique for modeling per capita electricity demand in Azerbaijan? What are the estimated price and income elasticities for electricity demand in Azerbaijan? Based on the estimated models, what do future scenarios suggest for the development of electricity demand in Azerbaijan through to 2025?

The rest of the paper is therefore organized as follows: Section 2 provides a review of relevant literature and Section 3 discusses the conceptual basis for the model of per capita electricity demand used for the research. This is followed by Section 4 that describes the different cointegration methods used for the research and presents the estimation results with Section 5 detailing the projection methodology, the projection assumptions, and the different forecast scenarios. Finally, Section 6 summarizes and concludes. 


\section{Discussion of Previous Electricity Demand Studies}

Numerous studies have attempted to model electricity demand. These include studies of specific countries and groups of countries or regions as well as of specific sectors, such as whole economy, residential, and industrial. Therefore, given the focus here is Azerbaijan electricity demand, this section briefly considers previous econometric studies of electricity demand for similar resource-rich small open developing economies followed by an extended review of previous Azerbaijan research on modeling and forecasting Azerbaijan electricity demand.

\subsection{Previous Electricity Demand Studies in Resource-Rich Small Open Developing Economies}

Table 1 presents a summary of previous econometric studies of electricity demand for resource-rich small open developing economies (excluding Azerbaijan). The studies chosen for inclusion are those that attempted to model econometrically electricity demand for resource-rich small open developing economies-it thus includes time series and panel data studies. It does not include papers where causality analysis was the primary focus (such as $[16,17])$. Neither does it include panel data studies where resource-rich small open developing economies were included but were a very minor portion of the overall panel (such as [18] given that the results are likely to be dominated by the other countries).

Table 1 shows that a number of various econometric techniques have been employed in the previous attempts to model electricity demand in resource-rich small open developing economies, although cointegration and the Error Correction Model (ECM) appears to dominate since the start of this millennium. It is also noticeable that the range of estimates presented in Table 1 vary considerably with the estimated long-run income elasticities varying from about 0.1 (for the industrial sector for Kuwait from [19]) to about 5.4 (for Bahrain from [20]). Similarly, the range of the estimated long-run price elasticities is from about zero (for a number of studies in Table 1) to about -3.4 (for Bahrain from [20]). Thus, there is no consensus of how price elastic or inelastic electricity demand is in these countries although the majority of studies generally do suggest that they are inelastic. Given this variation, conducting a systematic study for the whole economy of one resource-rich small open developing economy using various cointegration and ECM techniques should throw some light on whether the variation in previous studies is likely to be due to the different sectors and/or countries considered or the different techniques.

\subsection{Previous Azerbaijan Electricity Demand Studies}

For Azerbaijan in particular, it would appear that the only previous empirical academic studies related to electricity demand are a dissertation and a peer reviewed journal article. These are therefore, reviewed, before discussing other reports on Azerbaijan electricity demand forecasts, mentioned above. Using a model of intermittent supply, [21] assesses the welfare impact of reforms in the electricity sector in Azerbaijan using data from the Azerbaijan Household Energy Survey, implemented by the World Bank in December 2003-January 2004. It is concluded by [21] that there is a high willingness to pay for quality improvements in Azerbaijan and based on different price increase scenarios, suggests that the average price elasticity of electricity demand is -0.69 . However, these results are based on old and very limited data and the study does not attempt to forecast the future path of electricity consumption in Azerbaijan. 
Table 1. Selected studies of electricity demand for resource-rich small open developing economies.

\begin{tabular}{|c|c|c|c|c|c|c|c|c|}
\hline \multirow{2}{*}{ Study } & \multirow{2}{*}{ Period } & \multirow{2}{*}{ Country or Region } & \multirow{2}{*}{ Sector } & \multirow{2}{*}{ Methodology } & \multicolumn{2}{|c|}{ Income Elasticity } & \multicolumn{2}{|c|}{ Price Elasticity } \\
\hline & & & & & Short-Run & Long-Run & Short-Run & Long-Run \\
\hline Al-Sahlawi (1990) [22] & 1970-1985 & Saudi Arabia & Aggregate & OLS & 0.37 & 1.02 & Not reported & Not reported \\
\hline Eltony and Mohammad (1993) [23] & 1975-1989 & GCC & $\begin{array}{c}\text { Residential } \\
\text { Commercial } \\
\text { Industrial }\end{array}$ & OLS & $\begin{array}{l}0.20 \\
1.12 \\
0.60\end{array}$ & $\begin{array}{l}0.20 \\
2.37 \\
0.89\end{array}$ & $\begin{array}{l}-0.14 \\
-0.20 \\
-0.14\end{array}$ & $\begin{array}{l}-0.14 \\
-0.41 \\
-0.20\end{array}$ \\
\hline Eltony (1995) [19] & 1974-1989 & Kuwait & $\begin{array}{c}\text { Residential } \\
\text { Commercial } \\
\text { Industrial }\end{array}$ & OLS & $\begin{array}{l}0.09 \\
0.11 \\
0.02\end{array}$ & $\begin{array}{l}0.57 \\
1.93 \\
0.13 \\
\end{array}$ & $\begin{array}{l}-0.06 \\
-0.13 \\
-0.05\end{array}$ & $\begin{array}{l}-0.39 \\
-2.20 \\
-0.27\end{array}$ \\
\hline Eltony and Hoque (1997) [24] & 1975-1994 & Kuwait & $\begin{array}{l}\text { Aggregate } \\
\text { Commercial }\end{array}$ & ECM & $\begin{array}{l}0.57 \\
0.43\end{array}$ & $\begin{array}{l}0.65 \\
0.62 \\
\end{array}$ & $\begin{array}{l}-1.09 \\
-0.27 \\
\end{array}$ & $\begin{array}{l}-1.97 \\
-0.35 \\
\end{array}$ \\
\hline Diabi (1998) [25] & 1980-1992 & Saudi Arabia & Aggregate & $\begin{array}{c}\text { OLS, GLS, MLE, CHTA } \\
\text { and CCTA }\end{array}$ & 0.05 to 0.33 & 0.09 to 0.49 & $\begin{array}{c}-0.003 \text { to } \\
-0.12\end{array}$ & -0.14 to 0.01 \\
\hline Al-Sahlawi (1999) [26] & 1975-1996 & Saudi Arabia & $\begin{array}{l}\text { Aggregate } \\
\text { Residential } \\
\text { Industrial }\end{array}$ & OLS & $\begin{array}{l}0.21 \\
0.13 \\
0.08\end{array}$ & $\begin{array}{l}1.60 \\
0.70 \\
0.66\end{array}$ & $\begin{array}{c}-0.06 \\
-0.10 \\
\text { No price var }\end{array}$ & $\begin{array}{c}-0.46 \\
-0.50 \\
\text { ble included }\end{array}$ \\
\hline Al-Faris (2002) [20] & 1970-1997 & $\begin{array}{c}\text { Saudi Arabia } \\
\text { UAE } \\
\text { Kuwait } \\
\text { Oman } \\
\text { Bahrain } \\
\text { Qatar }\end{array}$ & Aggregate & Johansen cointegration & $\begin{array}{l}0.05 \\
0.02 \\
0.70 \\
0.02 \\
0.02 \\
0.08\end{array}$ & $\begin{array}{l}1.65 \\
2.52 \\
0.33 \\
0.79 \\
5.39 \\
2.65\end{array}$ & $\begin{array}{l}-0.04 \\
-0.09 \\
-0.08 \\
-0.07 \\
-0.06 \\
-0.18\end{array}$ & $\begin{array}{l}-1.24 \\
-2.43 \\
-1.10 \\
-0.82 \\
-3.39 \\
-1.09\end{array}$ \\
\hline Askari (2002) [27] & 1995-1999 & Iran & Residential & GLS & 0.11 & 0.16 & -0.97 & -1.36 \\
\hline Amini Fard and Estedlal (2003) [28] & $1967-2000$ & Iran & Residential & ECM & 0.00 & 0.24 & 0.00 & -0.59 \\
\hline Atakhanova and Howie (2007) [29] & 1994-2003 & Kazakhstan & $\begin{array}{c}\text { Aggregate } \\
\text { Industrial } \\
\text { Services } \\
\text { Residential }\end{array}$ & Panel GMM & $\begin{array}{l}0.72 \\
0.78 \\
0.75 \\
0.12\end{array}$ & $\begin{array}{c}\text { Not reported } \\
\text { Not reported } \\
\text { Not reported } \\
\quad 0.59\end{array}$ & $\begin{array}{l}0.00 \\
0.00 \\
-0.12 \\
-0.22\end{array}$ & $\begin{array}{c}\text { Not reported } \\
\text { Not reported } \\
\text { Not reported } \\
\quad-1.10\end{array}$ \\
\hline Eltony and Al-Awadhi (2007) [30] & 1975-2003 & Kuwait & Commercial & ECM & 0.34 & 0.50 & -0.33 & -1.64 \\
\hline Eltony and Al-Awadhi (2007) [31] & 1975-2005 & \multicolumn{7}{|c|}{ (Energy demand actually modeled, but consists predominately of electricity.) } \\
\hline Pourazarm and Cooray (2013) [32] & 1967-2009 & Iran & Residential & ARDLBT & $\begin{array}{c}0.04 \text { (But } \\
\text { insignificant) }\end{array}$ & 0.58 & $\begin{array}{c}-0.03 \text { (But } \\
\text { insignificant) }\end{array}$ & 0.00 \\
\hline Atalla and Hunt (2016) [33] & 1985-2012 & $\begin{array}{c}\text { Saudi Arabia } \\
\text { Oman } \\
\text { Kuwait } \\
\text { Bahrain }\end{array}$ & Residential & STSM & $\begin{array}{l}0.00 \\
0.72 \\
0.30 \\
0.00\end{array}$ & $\begin{array}{l}0.48 \\
0.86 \\
0.43 \\
0.71\end{array}$ & $\begin{array}{c}-0.10 \\
-0.09 \\
0.00 \\
0.00\end{array}$ & $\begin{array}{c}-0.10 \\
-0.10 \\
0.00 \\
0.00\end{array}$ \\
\hline
\end{tabular}

Note: ARDLBT = Autoregressive Distributed Lag Bound Testing model; GMM = Generalized Method of Moments; GLS = Generalized Least Squares; ECM = Error Correction Model; MLE = Maximum Likelihood Estimator; CHTA = Cross-sectionally Heteroskedastic and Timewise Autoregressive model; and CCTA = Cross-sectionally Correlated and Timewise Autoregressive model; STSM = Structural Time Series Model; CIS = Commonwealth of Independent States; UAE = United Arab Emirates; GCC = Gulf Cooperation Council. 
For the period 1990 to 2009, using annual panel data for the Commonwealth of Independent States (CIS), [34] investigated the relationship between electricity consumption and economic growth. The CIS countries were divided by [34] into three income level groups with Azerbaijan in the high-income level group. Using Pedroni co-integration tests and Panel Fully Modified Ordinary Least Squares (FMOLS) and Auto-Regressive Distributed Lag (ARDL) methods, [34] found a positive relationship between economic growth and electricity consumption with Granger causality tests suggesting that there is unidirectional causality running from GDP to electricity consumption in the short run and bidirectional causality in the long run. The estimated speed of adjustment coefficient was found to be -0.41 with an income elasticity of 0.52 from the FMOLS estimation and 0.77 from the ARDL estimation. Although [34] provide some insights concerning electricity-consuming behavior in the CIS countries, in general their use of panel data ignores country specific features. Additionally, they only consider economic growth as an explanatory variable ignoring other important determinants of electricity consumption, such as price. Moreover, the short time span used effectively ignores the substantial change in electricity consumer behavior since 2010 and the study does not attempt to forecast future path of electricity consumption in Azerbaijan.

As far as is known, the first available study that provides an electricity demand forecast for Azerbaijan is [11], which has since been updated several times and at the time of writing the last available was from 2013 [12]. The most recent projections are for up to 2017, with GDP growth in 2014 assumed to be over $11.0 \%$ but decreasing to almost $5.0 \%$ in 2017 with the income elasticity assumed to be 1.5 .

The demand forecast prepared by [12] was reviewed by [15] and considered three scenarios (central, high, and highest) with annual real GDP growth rates of $4 \%, 6 \%$, and $7 \%$, respectively-similar to [12]. Using the same income elasticities as [12,15] produced lower forecast values for 2017 of 27,000 GWh compared to 30,000 GWh by [12]. Unfortunately, [15] does not mention the methodology used to generate their forecasts. In addition, [14], based principally on the electricity demand forecasts provided by [11], applied the previous year's GDP growth rate of $5.1 \%$ for 2020 and onwards and found projected electricity demand in 2025 to be $42,000 \mathrm{GWh}$-being quite close to [15]'s projections. Again, [14] unfortunately does not explicitly report the methodology used to produce the forecasts.

The Power Sector Master Plan of Azerbaijan was updated by [13] for the period 2013-2025 taking $[12,15]$ as starting points and using data for the period 2009 to 2012 . By assuming that real GDP growth would remain constant at $4.0 \%$ over the forecast period, taken from [35], they produced high growth and slow growth scenarios for future electricity demand. For the slow growth scenario- that [13] characterized as an unfavorable social and economic performance of the country (such as the changes in world market prices or reductions in foreign direct investment) - it was assumed that real GDP growth would be low with an income elasticity assumed to be 0.8 (taken from [15]). For the high growth scenario-that [13] characterized as a more favorable scenario-the opposite situation was assumed, with an income elasticity assumed to be 1.5 (which represents the central case in $[11,15])$. The results from [13] suggest that total Azerbaijan electricity demand would increase to $34,792 \mathrm{GWh}$ by 2025 in what they call the base scenario. Whereas, the slow scenario case suggests that total electricity demand would reach 31,389 GWh by 2025 , being about $10 \%$ lower than in the base case. For the high growth scenario, [13] suggests that electricity demand would reach 44,839 GWh in 2025-being some $29 \%$ higher than the base case. Again, as with previous studies, the methodology used is not reported and it appears that GDP is the only explanatory variable considered in the analysis.

The above highlights the number of perceived shortcomings with the limited number of past studies that have attempted to model and/or forecast electricity demand in Azerbaijan. These include in particular: (i) the use of only GDP as an explanatory variable and thus the omission of other important drivers such as price, temperature or other factors, which potentially could result in spurious projections; and (ii) the short time periods used for the analysis without any small sample bias correction. Furthermore, although the previous studies use time series data, they did not address 
the issue of data non-stationarity that if not dealt with appropriately, can also result in spurious inferences and projections.

Consequently, to overcome these weaknesses, the research undertaken here analyzes the unit root characteristics of the data and employs different cointegration methods as a robustness check, to investigate the relationship amongst the variables using data covering the period 1995-2013. Moreover, Non-oil GDP is used instead of total GDP as the activity driver since total GDP is heavily influenced by oil-price volatility, which if used would arguably mislead any modeling and forecasting exercise given the substantial change in oil prices that occurred after the estimation period. Furthermore, the real electricity price, heating degree-days, and cooling degree-days are included in the analysis. The next section discusses this selection of variables by considering the conceptual framework for specifying a per capita electricity demand function before considering the actual econometric techniques considered for the research.

\section{Electricity Demand Function Specification and Data}

\subsection{Per Capita Electricity Demand Function}

Electricity demand relationships have been estimated for a number of countries and sectors, such as [36-40] amongst others as well as those summarized in Table 1 for resource-rich small open developing economies. A further study by [41] considered whole economy electricity demand for Sri Lanka, and the research undertaken here follows a similar conceptual framework as detailed below.

Similar to [41], it is assumed that there exists a long-run equilibrium demand relationship between per capita electricity consumption, economic activity and the real electricity price, which can be expressed as the following function:

$$
E=f(P, G D P, t)
$$

where, $E, P$, and GDP denote total final electricity consumption per capita, the real electricity price, and real Non-oil GDP per capita, respectively; $t$ is the underlying energy demand trend (UEDT) capturing changes in the technical progress of the appliance stock (and other exogenous behavioral changes). Note that it has been argued that the UEDT should be stochastic in energy demand models (for example see [42,43]). However, given that the focus here is on using and comparing cointegration techniques the trend is constrained to be deterministic and although any stochastic trend is implicitly represented by the non-stationary variables in the cointegration analysis, it is not possible to identify explicitly the impact of an exogenous stochastic trend on electricity demand.

For econometric estimation purposes, Equation (1) can be specified as a log-linear specification given by:

$$
e_{t}=\theta_{0}+\theta_{1} p_{t}+\theta_{2} g d p_{t}+\theta_{3} t+\xi_{t}
$$

where $e, p$ and $g d p$ indicate the natural logarithm expression of $E, P$, and GDP, respectively; $\theta_{1}$ and $\theta_{2}$ are the long-run elasticities of per capita electricity demand with respect to price and income; $\xi_{t}$ is a random error term; and $\theta_{3}$ is the average rate of exogenous technical change. Equation (2) is a standard energy demand specification found in the literature; although, this is often augmented with other variables that are believed to impact energy demand - for example, [44] included average annual temperature and rainfall and [45] included different population age groups. Here, the short-run analysis detailed in the methodology section below, is augmented with HDD and CDD variables.

\subsection{Data}

Given the electricity demand model specified above the following details the Azerbaijani data used for estimation by employing the techniques outlined in the next section. All data are annual for the period 1995 to 2013. Note some data are available back to 1990; however, Azerbaijan experienced a deep socio-economic recession in the early 1990s resulting in very volatile economic growth and inflation, making it very difficult for any meaningful econometric modeling with data prior to 1995. 
Moreover, Non-oil GDP data are not publically available before 1995-hence data used for the analysis in this paper starts in 1995. The variables of interest are detailed below and summarized in Table 2.

- $\quad E$ is electricity consumption per capita. This is equal to total final electricity consumption in TWh divided by population in millions. The total final electricity consumption data are collected from the International Energy Agency Database in Mtoe and then converted to TWh in order to be consistent with the electricity price [8]. Population data comes from the World Bank Database [4].

- $\quad P$ is the real electricity price. Nominal retail electricity prices in Azerbaijani New Manat (AZN) are administratively set by the government (being the same for the industrial, residential, and commercial sectors) and are collected from the various Statistical Yearbooks of the State Statistical Committee of the Republic of Azerbaijan [9]. The real electricity prices are in 2005 AZN, found by deflating the nominal prices by the Consumer Price Index (CPI), $2005=100$ collected from [9].

- GDP is real Non-oil GDP per capita. This is calculated by deflating nominal Non-oil GDP in million AZN by the CPI, $2005=100$ and then dividing by population in millions. Nominal Non-oil GDP is retrieved from [9].

- GDPT is real total GDP per capita. This is calculated in a similar way to GDP-nominal total GDP in million AZN is deflated by the CPI, $2005=100$ and then divided by population in millions Nominal total GDP is retrieved from [9].

- $\quad H D D$ and $C D D$ are heating degree-days and cooling degree-days, respectively. These are summary variables of weather conditions that are considered given they might influence electricity demand. For HDD the reference temperature is $18^{\circ} \mathrm{C}$. For CDD the reference temperature is $21^{\circ} \mathrm{C}$. Both HDD and CDD come from the [46] database, where population-weighted degree-days were constructed for just under 150 countries for the period 1948 to 2013. The weather variables from [46] are calculated using a sophisticated degree-days methodology by addressing issues such as, limited geographical availability, temporal and spatial aggregation, the lack of accounting for various climatic factors, and the restrictive use of a singular reference temperature.

Table 2. Descriptive statistics of the variables over 1995-2013.

\begin{tabular}{ccccccc}
\hline & $\boldsymbol{E}$ & $\boldsymbol{P}$ & GDP & GDPT & HDD & CDD \\
\hline Mean & 1.76 & 0.03 & 970.97 & 1653.42 & $14,690.97$ & $18,432.05$ \\
Median & 1.77 & 0.02 & 799.07 & 1125.45 & $14,563.70$ & $18,378.19$ \\
Maximum & 2.31 & 0.05 & 2053.05 & 3376.73 & $16,143.83$ & $19,973.30$ \\
Minimum & 1.35 & 0.02 & 357.23 & 397.81 & $12,821.17$ & $16,511.11$ \\
Standard Deviation & 0.25 & 0.01 & 551.69 & 1132.71 & 734.86 & 769.38 \\
\hline
\end{tabular}

Figure 1 compares real Non-oil GDP with real total GDP and shows that, although the minimum and maximum values of both variables are relatively similar as shown in Table 2, the latter is far more volatile, with the standard deviation being about twice that of the former. This is not surprising given that real total GDP is heavily influenced by fluctuating international oil prices, which arguably does not adequately reflect the true economic activity of Azerbaijan.

Furthermore, Figure 1 illustrates that real total GDP has a new regime (development trend) after 2004 until 2008 with very high growth rates-being around 37\% in 2006. Again, this illustrates how real total GDP is largely determined by international oil prices and the oil sector of the economy, which grew very rapidly after 2004 — especially after the Baku-Tbilisi-Ceyhan oil export pipeline was launched in 2006, which peaked in 2008. Following this, real total GDP declined by $14 \%$ in 2009 given the fall in oil prices. This illustrates the connection between oil price volatility and real total GDP via oil export revenues and government expenditure (see [3] inter alia for further discussion). In summary, real total GDP appears to be too volatile to reflect the economic activity of Azerbaijan, hence real Non-oil GDP is used as the activity driver in the estimated per capita electricity demand relationship (which, for simplicity, is referred to as just GDP in the modeling section below). 
- GDP - GDPT

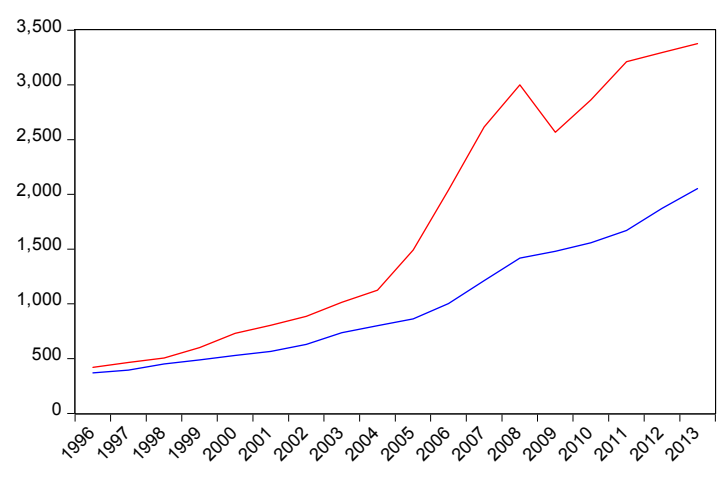

- GDP \% change - GDPT \% change

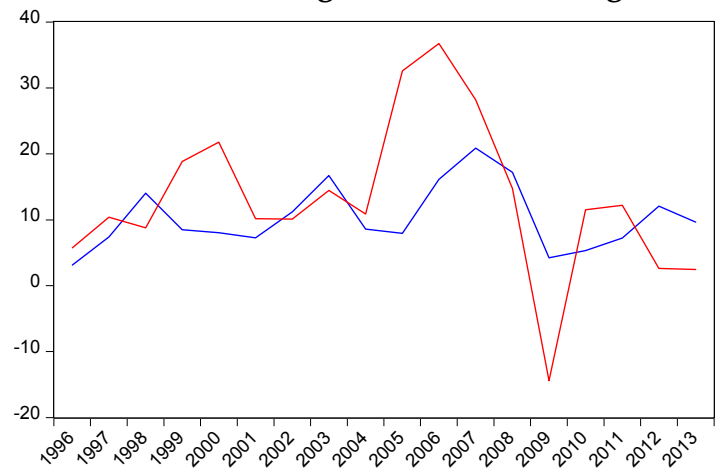

Figure 1. Level and growth rates of Non-oil GDP and Total GDP.

Figure 2 presents the natural logarithm of the variables and their annual changes (represented by $\Delta$ ) used in the analysis starting from the same year, 1996, for ease of comparison. These illustrate that electricity consumption per capita grew on average by $3.9 \%$ per annum, which represents an increase of about 1.5 times from 1.6 MWh per capita in 1996 to 2.3 MWh per capita in 2006. However, in 2007, electricity consumption in Azerbaijan decreased by $20.2 \%$ followed by declines to $1.8 \mathrm{MWh}$ per capita in 2008 and 1.4 MWh in 2009 but recovered again in 2010 and reached the 1990s levels again in 2013.

As stated, the nominal electricity price (or more correctly the tariff) in Azerbaijan is administratively regulated by the Tariff (Price) Council of Azerbaijan Republic [47], who also sets tariffs on other goods and services such as, passenger transportation, communication services, and water supply. Thus, implicitly the price is highly subsidized by the government, similar to many other natural resource (oil and gas) rich developing economies and therefore relatively cheap compared to other countries, as mentioned in the Introduction. However, following the recommendation from international organizations (such as the International Monetary Fund, the World Bank, and the Asian Development Bank), since 2006 the Azerbaijan government has attempted to cut the subsidy. By doing so, it increased the nominal retail price for electricity three times, from 0.02 to $0.06 \mathrm{AZN} / \mathrm{kWh}$ in 2007 [47]. As shown in Figure 2, the effect of this is that the real price of electricity fell gradually until 2006 when it rose sharply but declined gradually again thereafter. More recently, in July 2016, the Tariff (Price) Council of Azerbaijan Republic increased the nominal price again by about $17 \%$ and at the time of writing the tariff is $0.07 \mathrm{AZN} / \mathrm{kWh}$ [47]; however, this is after the estimation period so it is not shown in Figure 2, nonetheless, this increase is considered in the forecast scenario section below.

Figure 2 also confirms the general upward trend over the estimation period in Azerbaijan real Non-oil GDP shown in Figure 1. Real Non-oil GDP actually grew by about $65 \%$ in total from 2005 to 2008 but its pace of growth slowed during the 2009 to 2011 period amid the global financial-economic crisis with average growth of about $18 \%$ over the 2005-2008 period but declining to about $6 \%$ over the 2009-2011 period. Finally, it can be seen from Figure 2 that the two weather degree variables show some variation that might be expected to impact on electricity demand. The next section therefore introduces the various econometric methods used in the analysis with these data to produce the estimated electricity demand models. 

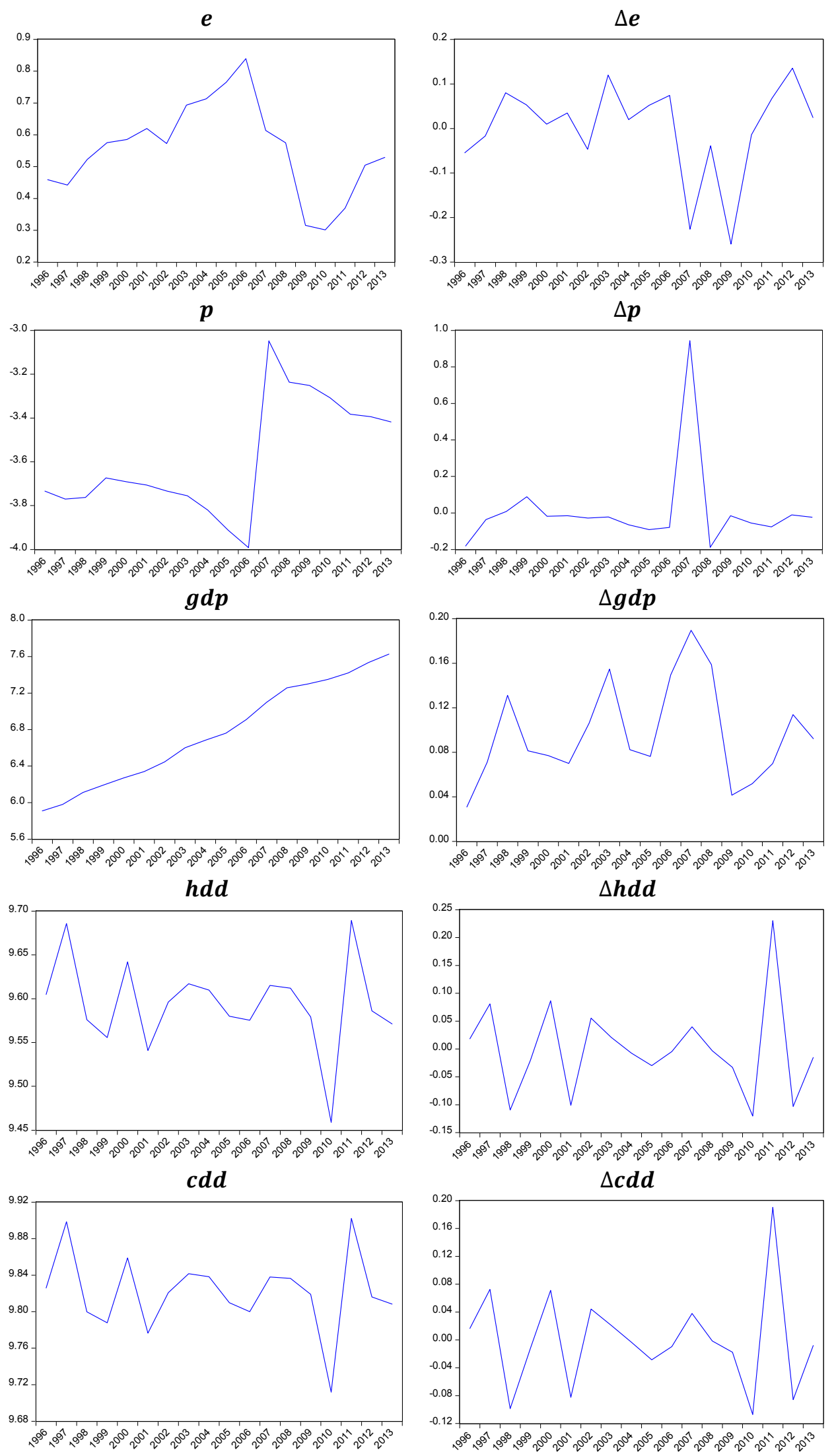

Figure 2. Level of Natural Logarithm and Growth Rates of Variables. 


\section{Cointegration Methodologies and Estimated Models}

\subsection{Methodologies}

A wide range of econometric methodologies and techniques has been employed for estimating energy demand relationships. However, according to [48], cointegration analysis is a key application having markedly changed the approach of researchers and practitioners to electricity demand forecasting. Therefore to avoid making this paper unduly long and given that the focus of the special issue is forecasting energy time series data, the previous econometric methodological literature is not reviewed here, instead, this section details the time-series cointegration techniques considered and applied to Azerbaijan electricity demand below.

This section starts by first briefly describing Unit Root (UR) tests followed by an explanation of the Johansen, Autoregressive Distributed Lags Bounds Testing (ARDLBT), and Engle-Granger (EG) cointegration methods as well as long-run estimators, namely the Dynamic Ordinary Least Squares (DOLS), Canonical Cointegrating Regression (CCR), and Fully Modified Ordinary Least Squared (FMOLS). It concludes by detailing Error Correction Modeling with a General to Specific Modeling strategy. It should be noted that these are not the only time series approaches for analyzing data and not the only approaches that have been used for estimating energy demand relationships using time-series data. See for example, the Structural Times Series Model approach by [49], which is advocated by [42,43] for estimating energy demand relationships. Such approaches are not considered here given the focus is on the cointegration methodology — for a discussion of the different approaches for modeling and forecasting Sri Lankan electricity demand, see [41].

\subsubsection{Unit Root Test}

According to the cointegration concept, if variables are non-stationary and there is no long-run (cointegrating) relationship among them, then results from the regression of these variables are spurious. This means that only stationary variables should be used in regression analysis. Alternatively, if there is a cointegration amongst non-stationary variables, then the regression results are not spurious and can be interpreted as a long-run relationship ([50] inter alia). Since most economic variables tend to trend over time stochastically, it is therefore important for this methodology to initially test for the stationarity of the variables using UR tests in order to prevent spurious results. There are many UR tests that could be considered; however, the most widely used UR tests in empirical time series research are used here- the Augmented Dickey Fuller (ADF) test [51] and the Philips-Perron (PP) test [52].

To undertake a UR test for a given variable (say $y_{t}$ ), the ADF equation, which includes an intercept and trend, can be expressed as:

$$
\Delta y_{t}=b_{0}+b_{1} t+b_{2} y_{t-1}+\sum_{i=1}^{l} \gamma_{i} \Delta y_{t-i}+\omega_{t}
$$

where, $b_{0}$ is a constant term; $\Delta$ indicates the first difference operator; $l$ represents the number of lags; $t$ is a linear time trend and the white noise errors are denoted by $\omega_{t}$. The $t$-statistic for $b_{2}$ is the ADF sample value. If this value is smaller than the critical ADF values, in absolute terms, at different significance levels, then the null hypothesis of UR cannot be rejected and hence it is concluded that $y_{t}$ is a non-stationary variable. Otherwise, if the value is greater than the critical ADF values, in absolute terms, the null hypothesis of UR can be rejected meaning that $y_{t}$ is not non-stationary. The only difference in the PP test to the ADF test is that it uses non-parametric statistical methods, rather than lags of the dependent variable $\left(\Delta y_{t-i}\right)$ to correct for the serial correlation problem in the residuals (see [52] for a detailed discussion). Note that additionally, as a robustness check, UR tests with a structural break are used when testing the stationarity of $e$ and $p$ given that Figure 2 suggests that both variables might have some structural breaks in their development path $($ see $[53,54]$ for details of the 
development and application of the tests). Similar tests were used by [23] that included Azerbaijan as part of the CIS panel. Further discussion of the UR tests can be found in [51-55] among others.

Once the integration order of all the variables being considered for the long-run relationship has been determined, the Johansen cointegration test can be employed to determine the number of cointegrating relationships that exist among them; this being the only test that can reveal if there is more than one cointegrating relationship between the variables (see $[55,56]$ inter alia). If the Johansen cointegration test finds only one cointegrating relationship, then it is useful, as a robustness check, to use other cointegration methods, such as the ARDLBT (and EG methods) to compare the findings. Once cointegrating relation is found among the variables, then long- and short-run parameters, as well as the speed of adjustment coefficients can be estimated employing the estimation procedures discussed below.

\subsubsection{Different Cointegration Methods}

As mentioned above, once the time series properties of the variables are known then there are several techniques available for estimating the cointegrating relationships. This sub-section therefore outlines the state of the art techniques that are used in the empirical analysis undertaken here.

\section{The Johansen Cointegration Method}

The full information maximum likelihood of the Vector Error Correction Model (VECM) of $[56,57]$ is as follows:

$$
\Delta z_{t}=\Pi z_{t-1}+\sum_{i=1}^{k-1} \Gamma_{i} \Delta z_{t-i}+\mu+\psi_{t}
$$

where, $z_{t}$ is a $(n \times 1)$ vector of the $n$ endogenous/modeled variables in interest, $\mu$ is a $(n \times 1)$ vector of constants, $\Gamma$ represents a $(n \times(k-1))$ matrix of short-run coefficients, $\psi_{t}$ denotes a $(n \times 1)$ vector of white noise residuals, and $\Pi$ is a $(n \times n)$ coefficient matrix. If the matrix $\Pi$ has reduced rank $(0<r<n)$, it can be split into a $(n \times r)$ matrix of loading coefficients $\alpha$, and a $(n \times r)$ matrix of cointegrating vectors $\beta$. The former indicates the importance of the cointegration relationships in the individual equations of the system and of the speed of adjustment to disequilibrium, while the latter represents the long-term equilibrium relationship, so that $\Pi=\alpha \beta^{\prime}$.

Testing for cointegration, using Johansen's reduced rank regression approach, centers on estimating the matrix $\Pi$ in an unrestricted form, and then testing whether the restriction implied by the reduced rank of $\Pi$ can be rejected. In particular, the number of the independent cointegrating vectors depend on the rank of $\Pi$, which in turn is determined by the number of its characteristic roots that are different from zero. Max-eigenvalue and Trace test statistics are used to test for nonzero characteristic roots.

Significance of a given variable implies that the null hypothesis of corresponding $\beta$ is zero can be rejected, while stationarity or trend stationarity of a variable assumes that $\left(\begin{array}{llll}1 & 0 & 0\end{array}\right)^{\prime}$ restriction on long-run coefficients cannot be rejected. A variable is weakly exogenous if the null hypothesis of corresponding $\alpha$ is zero cannot be rejected. The weak exogeneity of a variable assumes that disequilibrium in the long-run relationship does not feed back onto this variable. Detailed discussion and empirical application of these tests can be found in [57-59]. Note that $[60,61]$ among others, discuss that if the long-run determinants of variable in interest are weakly exogenous to the cointegration system, then it is possible to move to a single equation ECM instead of VECMs.

\section{Small Sample Bias Correction in the Johansen Method}

According to [62], the Max-eigenvalue or Trace test statistics are biased to reject the null hypothesis of no cointegration, in the case of a small number of observations. Given this, $[63,64]$ propose a $\frac{T-k n}{T}$ correction to the Max-eigenvalue or Trace test statistics in the case of small samples; where $k$ is the lag length of the underlying Vector Autoregressive (VAR) model in levels, while $n$ and $T$ are the number 
of endogenous variables and observations, respectively. Given the sample size for Azerbaijan, this correction is used in the empirical analysis undertaken here.

\section{ARDLBT Method}

One of the alternative single equation-based cointegration approaches applied is the ARDLBT method proposed by $[65,66]$. An argument for using this approach is that according to $[55,66]$ the autoregressive distributed approach to cointegration is superior (i.e., is more efficient) in small samples than its counterparts (including VAR methods). The method also has other advantages, such as: being easy to perform by using just Ordinary Least Squares (OLS); it estimates the long- and short-run coefficients simultaneously; and, importantly, it can be applied regardless of whether regressors are integrated of order one, i.e., I(1), or integrated of order zero, i.e., I(0), or a mixture of the two. Consequently, given the sample size of the Azerbaijani data set used here, this approach is thought to be particularly appropriate for the empirical analysis undertaken. Detailed discussion of the approach can be found in [65-67].

\section{Small Sample Bias Correction in ARDLBT Approach}

Note that [67] have calculated the upper and lower critical values of the F-distribution by using large sample sizes of 500 and 1000 as well as 20,000 and 40,000 replications, respectively. However, $[68,69]$ argue that these critical values are not accurate for small sample sizes since they are calculated based on large sample points. In fact, [69] compared the critical values generated using 31 observations with the values reported in [65] for the case of four regressors and at the 5\% significance level showing that the critical value (3.49) from [67] is $18.3 \%$ lower than his generated critical value (4.13). Therefore, [69] has produced critical values for small sample sizes ranging from 30 to 80 data points, which are used in the research here given the sample size.

\section{EG Approaches}

The final alternative approach considered in the empirical work undertaken here is based on the EG method for cointegration [50], which is a residual-based method using a two-step process. The original EG method proposed by [50] estimates the long-run relationship using OLS in the first step of the process, however, if there is cointegration, the estimated coefficients are consistent but the standard errors are incorrect; hence, the original EG method is not used here. Instead, three different ways of estimating the long-run level relationship are employed here for the first step given they correct for the biases, these are DOLS, CCR and FMOLS (see [70-82] for detailed discussion). For all three methods, the existence of cointegration is tested by checking for the stationarity of the residuals from the level equations using the critical values from [83] instead of [84]. It is recognized that the EG method has some drawbacks and is therefore seen as being inferior to the Johansen and ARDLBT methods. However, given the numerous application of the EG method in previous energy demand studies (for example see the early attempt by [85] and a similar comparison for Sri Lanka [41]) they are used here for a contrast and as a robustness check.

Furthermore, conventional inference based on t-statistics and/or F-statistics cannot be applied, if the parameters of the long-run Equation (5) below are estimated using OLS, because given the absence of any dynamics in the equation cause the results to be biased (see [86] for further discussion). In addition, $[80,86]$ show that the bias is considerably large in small samples and consequently, some new methods have been developed to overcome this problem. According to [82], who comprehensively reviews these new alternative methods, they can be classified into two groups. The first group mainly attempt to include dynamics in the static equation by using lags and leads of differenced variables (see [75-77]). Whereas the second group deals with a non-parametric adjustment of the OLS estimated long-run parameters (see [74-79]). Moreover, [80] argues that using dynamics is preferable, even though it leads to an over-parameterization - especially in the case of small samples. Additionally, [80], based on Monte-Carlo simulations, show that DOLS outperforms its alternatives in small samples. 
Therefore, the EG approach is applied to the Azerbaijani data in this research with the three long-run estimators, namely CCR, FMOLS (which uses semi-parametric correction to the estimated long-run parameters) and DOLS (which includes dynamics in the long-run equation). As mentioned above, the CCR, FMOLS, and DOLS estimators provide unbiased and efficient coefficient estimates and standard errors thus making it possible to use conventional inference, such as t-tests for the significance of the estimated coefficients.

In summary, the process for estimating such EG models can be divided into the following steps (see [50,55] among others):

(i) For the first step, estimate a regression equation of the non-stationary variables that are integrated in the same order (usually I(1)):

$$
y_{t}=c_{0}+c_{1} x_{t}+\varepsilon_{t}
$$

where, $y$ and $x$ are the variables that are integrated in the same order; $c_{0}$ and $c_{1}$ are the coefficients to be estimated; $\varepsilon$ indicates the residuals; $t$ denotes time. The residuals from Equation (5) then need to be checked for stationarity using the UR tests outlined above. It is important to note that as [55] inter alia discus, the [83] critical values have to be used instead of [84]. If, from the test, the calculated residuals, $\hat{\varepsilon}_{t}$, are found to be stationary, then it can be concluded that the variables in Equation (5) are cointegrated, the estimation results are not spurious, and can therefore be considered as a long-run relationship.

(ii) The second step of the EG procedure involves estimating the short-run ECM, which is explained in the next section.

\subsubsection{Error Correction Model with the General to Specific Modeling Strategy}

The previous sections detailed the various way in which long-run relationships can be obtained, all of which are used in the modeling of electricity demand in Azerbaijan detailed below. However, before moving on to the estimation, this section outlines how short-run relationships among variables are analyzed using an ECM, which can be employed if the variables are cointegrated. Otherwise, short-run analysis is conducted by means of a VAR and/or an ARDL of stationary variables, where an error correction term is dropped since the variables are not cointegrated.

If all level variables, except a variable in interest, are weakly exogenous to the cointegrating system, then it is possible to proceed to a single equation ECM of the variables of interest (see $[60,61]$ among others) without the loss of any useful information. The ECM is estimated using the stationary condition of the variables and one lagged level the residuals of the long-run equation, $\hat{\varepsilon}_{t-1}$, which are derived from the methods for obtaining the long-run relationship outlined above:

$$
\Delta y_{t}=\varphi_{0}+\varphi_{y} \hat{\varepsilon}_{t-1}+\sum_{i=1}^{p 1} \varphi_{1 i} \Delta y_{t-i}+\sum_{i=0}^{p 2} \varphi_{2 i} \Delta x_{t-i}+v_{t}
$$

where, $p 1$ and $p 2$ are the lag orders and $v_{t}$ is the residuals that are assumed to be white noise. [50] shows that if variables are cointegrated, then there should be an ECM representation of them and vice versa, with $\hat{\varepsilon}_{t-1}$ referred to as the Error Correction Term (ECT). Furthermore, according to [50], if there is a stable cointegration relationship between the variables, then the coefficient on ECT, i.e., $\varphi_{y}$ in Equation (6), must be negative and statistically significant, is known as the Speed of Adjustment (SoA) coefficient, and is usually between -1 and zero.

The idea of the General to Specific Modeling strategy with an ECM is to initially estimate the general ECM, Equation (6), with the maximum lags of the right hand side variables and then exclude statistically insignificant variables, while comparing standard errors of regressions and performing a battery of serial correlation, normality, heteroscedasticity, and misspecification tests, in order to obtain the most parsimonious specification (see [87] for a detailed survey on the strategy). Note that Equation (6) can be considered as a general ECM for the Johansen, EG, and ARDLBT approaches here, where only the ECTs are replaced accordingly. In addition, the maximum lag in an ECM can be 
specified using a time-dependent rule, information criteria (such as Schwarz and Akaike), or based on the frequency of the time series used (see $[53,88,89])$. For example, [53] suggests that if the frequency is quarterly and the number of observations is small-then the maximum lag order of four should be chosen. Likewise, if the frequency is annual and the sample size is small (as in the case here for the Azerbaijan data), then one or two lags should be specified as a maximum.

\subsection{Results}

As explained, the electricity demand model is estimated using the approaches detailed in the previous section and as explained in the data section, for the empirical analysis, the variables in natural logarithms used are $e, p, g d p, h d d$ and $c d d$. In line with the methodology above, the ADF and PP tests are undertaken to determine order of integration of the level and first difference of the variables. Initially, the full specifications, with both a constant and a trend are considered, then, depending on the significance of the deterministic regressors, the final UR test equations include only an intercept, an intercept and trend, or none of them; Table 3 reports the results.

Table 3. The Unit Root test results.

\begin{tabular}{cccccccccc}
\hline \multirow{2}{*}{ Variable } & \multicolumn{3}{c}{ The ADF Test } & \multicolumn{5}{c}{ The PP Test } \\
\cline { 2 - 10 } & Test Value & $C$ & $t$ & None & $k$ & Test Value & $C$ & $t$ & None \\
\hline$e$ & -2.992 & $\mathrm{x}$ & $\mathrm{x}$ & & 2 & -1.767 & $\mathrm{x}$ & $\mathrm{x}$ & \\
$p$ & -2.851 & $\mathrm{x}$ & $\mathrm{x}$ & & 0 & -2.851 & $\mathrm{x}$ & $\mathrm{x}$ & \\
$g d p$ & -2.675 & $\mathrm{x}$ & $\mathrm{x}$ & & 1 & -2.497 & $\mathrm{x}$ & $\mathrm{x}$ & \\
$h d d$ & $-4.737^{* * *}$ & $\mathrm{x}$ & & & 1 & $-8.051^{* * *}$ & $\mathrm{x}$ & & \\
$c d d$ & $-5.081^{* * * *}$ & $\mathrm{x}$ & & & 1 & $-10.460^{* * *}$ & $\mathrm{x}$ & & \\
$\Delta e$ & $-3.569^{* * *}$ & & & $\mathrm{x}$ & 0 & $-3.6077^{* * *}$ & & & $\mathrm{x}$ \\
$\Delta p$ & $-5.109^{* * *}$ & & & $\mathrm{x}$ & 0 & $-5.370^{* * *}$ & & & $\mathrm{x}$ \\
$\Delta g d p$ & $-3.987^{* * *}$ & $\mathrm{x}$ & & & 1 & $-3.052^{*}$ & $\mathrm{x}$ & & \\
\hline
\end{tabular}

Notes: ADF and PP denote the Augmented Dickey-Fuller and Phillips-Perron tests, respectively. Maximum lag order is set to two and optimal lag order $(k)$ is selected based on Schwarz criterion in the tests; ${ }^{*}$ and ${ }^{* * *}$ denote rejection of the null hypotheses at the $10 \%$ and $1 \%$ significance levels, respectively; The critical values for the tests are taken from [84]. Estimation period: 1995-2013. None means that neither intercept nor trend is included in test equation. Note again that final UR test equation can include one of the three: intercept $(C)$, intercept, and trend $(t)$ and none of them (None). $\mathrm{x}$ indicates that the corresponding option is selected in the final UR test equation.

Both the ADF and PP test statistics clearly fail to reject the null hypothesis of unit root for the $e, p$, and $g d p$ variables but rejects the null hypothesis for the first differences of them. Both ADF and PP test equations for the first difference of $e$ and $p$ include neither the trend nor intercept. The insignificance of both deterministic regressors is consistent with Figure 2, which suggests that the growth of both variables are highly likely to have a mean-zero process-in fact, for the period 1996 to 2013 the mean values of $\Delta e$ and $\Delta p$ are 0.0009 and 0.007 , respectively. As discussed in the methodological section, ADF with structural breaks tests are also run for $e$ and $p$. Figure 2 suggests that $p$ experienced a sudden break in 2007, whereas $e$ experienced a gradual structural break from 2007 up to 2010. Therefore, as a break type, an additive outlier is selected for $p$ and an innovative outlier for $e$, but both for 2007. Additionally a lag length of three is specified for $e$ given the innovative outlier and a lag order of two for $e$. Finally, a break in both intercept and trend is allowed. This gives calculated ADF statistics of -2.68 and -3.66 for $p$ and $e$, respectively compared to the critical values from [53] of $-3.87,-4.19$, and -4.71 at the $10 \%, 5 \%$, and $1 \%$ significance levels, respectively. Evidently, for $p$ and $e$, the null hypothesis of UR cannot be rejected in favor of the alternative hypothesis of trend stationary with break. Thus, the results from the ADF with breakpoint support those from the standard ADF and PP tests. Furthermore, the null hypotheses of a unit root for $h d d$ and $c d d$ are both rejected. Therefore, it can be concluded from the UR tests that $e, p$, and $g d p$ are integrated of order one, i.e., they are I(1) variables, whereas $h d d$ and $c d d$ are level stationary, i.e., they are $\mathrm{I}(0)$ variables. This implies that $h d d$ and $c d d$ do not contain any long-run information in explaining $e$; however, this does not rule out the possibility that they may be useful in explaining the short-run dynamics of $e$. It is worth noting that similar results were also found by $[36,48,90,91]$ in their electricity and energy demand modeling. 
Since the variable of interest, $e$, as well as $p$, and $g d p$ are found to be I(1) processes, it is meaningful to test whether a long-run cointegrating relationship exists between them. According to the cointegration concept, if there are $n$ variables, then there can be, at most, $n-1$ cointegrating relationships $([50,92]$ inter alia) that implies, in this case, a maximum of two. However, as explained above, only the Johansen approach is able to discover more than one cointegrating relationship (see $[55,86]$ among others); hence, given that three variables ( $e, p$, and $g d p)$ are considered here, the Johansen test for cointegration is considered first. To do this, a VAR with endogenous variables, $e, p$, and $g d p$ is constructed. Note that according to the Johansen cointegration approach, only the variables with the same order of integration can be cointegrated. It implies that $e, p$, and $g d p$ can be cointegrated but they cannot be cointegrated with $h d d$ and $c d d$ as the integration order of the former variables is I(1) and that for the latter variables is I(0). Therefore, $h d d$ and $c d d$ are excluded from this part of the cointegration analysis, which is in line with previous electricity demand analysis (such as $[48,91]$ ). In addition to the endogenous variables, an exogenous dummy variable for 2007 is included in the VAR to capture the sharp decline in $e$ and the very large increase in $p$ that year-the year that the government raised the nominal electricity price by three times. This dummy variable proves to be highly significant in both the $e$ and $p$ equations and helps to reduce the huge outliers in the residuals of these equations. Note that time trend was also included in the VAR as an exogenous variable; however, it was statistically insignificant in all three equations and hence excluded. Therefore, the VAR contains only an intercept and the dummy variable as deterministic regressors with initially a maximum of two lags set for the endogenous variables. However, both the lag selection criteria and the lag exclusion tests suggested that two lags was the optimum order so were maintained, which is intuitively appropriate given the small number of observations in the sample. The VAR with two lags successfully passes all the residual diagnostics as indicated in Panels A-C in Table 4. The Johansen cointegration test results from the transformed version of the VAR, which means that the resulting VECM with one-lag are presented in Table 4.

Table 4. The Vector Autoregressive model residual diagnostics and cointegration tests results.

\begin{tabular}{|c|c|c|c|c|c|}
\hline \multicolumn{6}{|c|}{ Panel A: Serial Correlation LM Test ${ }^{\text {a }}$} \\
\hline Lags & LM-Statisticb & \multicolumn{2}{|c|}{ Probability } & & \\
\hline 1 & 2.572 & \multicolumn{2}{|c|}{0.979} & & \\
\hline 2 & 13.550 & \multicolumn{2}{|c|}{0.139} & & \\
\hline 3 & 4.174 & \multicolumn{2}{|c|}{0.900} & & \\
\hline \multicolumn{6}{|c|}{ Panel B: Normality Test ${ }^{b}$} \\
\hline Statistic & $\chi^{2}$ & d.f. & Probability & & \\
\hline Skewness & 4.827 & 3 & 0.185 & & \\
\hline Kurtosis & 3.366 & 3 & 0.339 & & \\
\hline Jarque-Bera & 8.193 & 6 & 0.224 & & \\
\hline \multicolumn{6}{|c|}{ Panel C: Heteroscedasticity Test ${ }^{\mathrm{c}}$} \\
\hline White & $\chi^{2}$ & d.f. & Probability & & \\
\hline Statistic & 81.226 & 78 & 0.379 & & \\
\hline \multicolumn{6}{|c|}{ Panel D: Johansen Cointegration Test Summary } \\
\hline Data Trend: & None & None & Linear & Linear & Quadratic \\
\hline Test Type: & (a) No $C$ and $t$ & (b) Only C & (c) Only C & (d) $C$ and $t$ & (e) $C$ and $t$ \\
\hline Trace: & 1 & 1 & 1 & 1 & 1 \\
\hline Max-Eig: & 1 & 2 & 1 & 1 & 1 \\
\hline \multicolumn{6}{|c|}{ Panel E: Johansen Cointegration Test Results for Type c } \\
\hline Null Hypothesis: & $r=0$ & $r \leq 1$ & $r \leq 2$ & & \\
\hline$\lambda_{\text {trace }}$ & $41.065 * *$ & 11.049 & $0 . \overline{6} 35$ & & \\
\hline$\lambda^{\mathrm{a}}{ }_{\text {trace }}$ & 31.403 ** & 8.449 & 0.485 & & \\
\hline$\lambda_{\max }$ & $30.016^{* *}$ & 10.414 & 0.635 & & \\
\hline$\lambda^{\mathrm{a}}{ }_{\max }$ & $22.953^{* *}$ & 7.964 & 0.485 & & \\
\hline
\end{tabular}

Notes: ${ }^{a}$ The null hypothesis in the Serial Correlation LM Test is that there is no serial correlation at lag order $\mathrm{h}$ of the residuals; ${ }^{\mathrm{b}}$ System normality test with the null hypothesis of the residuals are multivariate normal; ${ }^{c}$ White Heteroscedasticity Test takes the null hypothesis of no cross terms heteroscedasticity in the residuals; $\chi^{2}$ is Chi-squared; d.f. means degree of freedom; $C$ and $t$ indicate intercept and trend. $r$ is rank of $\Pi$ matrix, i.e., number of cointegrated equations; $\lambda_{\text {trace }}$ and $\lambda_{\max }$ are the Trace and Max-Eigenvalue statistics, while $\lambda^{\mathrm{a}}$ trace and $\lambda^{\mathrm{a}}{ }_{\max }$ are adjusted version of them; ${ }^{* *}$ denotes rejection of the null hypothesis at the $5 \%$ significance level; Critical values for the cointegration test are taken from [93]; Estimation period: 1997-2013. As [94] shows, when a pulse dummy is included in a VAR a blip dummy (which is equivalent to the change in the pulse dummy) should be included in the VECM, which is the procedure followed here. 
Despite the economic drivers usually represented by the cointegration equation type (c), where there is an intercept but not trend, a check for the existence of cointegration in all possible combinations of the deterministic regressors is undertaken, i.e., in five test types. As [92,94] show, a pulse (blip) dummy does not distort the distribution of the critical values of the cointegration tests. However, they do make the sample values of the tests smaller and therefore reduce the chance of rejecting the null hypothesis of no cointegration. Even, in the presence of the dummy variables, the test statistics in almost all types indicate one cointegrated relationship among the variables as reported in Panel D of Table 4.

Since, the theoretical framework behind the estimation is demand side modeling of per capita electricity, Types (a), (b) and (e) should not be considered. Type (a) assumes that there is no intercept in the cointegrating relationship so there is no autonomous level of per capita electricity demand. Type (b) however, assumes that there is an intercept in the cointegrating relationship but no intercept in the VAR, thus implying that over the sample period the average growth in per capita electricity demand is zero, which is not the case here. Type (e) assumes that the per capita electricity demand contains a quadratic trend in the general VAR (one in the cointegrating relationship and another in the short-run part), which was not confirmed by the UR test results. Hence, only type (c) or (d) are applicable here. For type (d), where both an intercept and a linear trend are included in the cointegrated equation, the coefficient on income switches its sign from positive to negative, which is hard to explain and goes against economic intuition. Moreover, the normality condition of the VECM residuals is violated and income is not weakly exogenous to the cointegration parameters. It appears, therefore, that the trend is not part of the data generating process for per capita electricity demand in Azerbaijan. Unlike type (d), the theoretically expected signs for the coefficients of income and price are found and additionally, the residuals are normally distributed in type (c), where an intercept but no trend is included in the equation. Thus, it seems reasonable to choose type (c), thus there is no explicit role for the deterministic trend in the cointegration space.

The unadjusted and adjusted (for small sample bias) values of the Trace and Max-eigenvalues statistics are given in Panel E of Table 4. This shows that all tests reject the null hypothesis of no cointegration and fail to reject the null hypotheses of more than one long-run relationship among the variables; this suggests that there is only one cointegrating relationship among $e, p$, and $g d p$.

Before making any inference about the cointegration space, the statistical significance, stationarity, and weak exogeneity of the level variables in that space of the VECM are tested as summarized in Table 5. Panel A shows that the sample values of the $\chi^{2}$ distribution are greater than the critical values at the $1 \%$ significance level, meaning that $e, p$, and, $g d p$ are statistically significant. In addition, the multivariate test results for stationarity shown in Panel B indicate that none of the variables are stationary and therefore confirm the univariate UR tests results, given in Table 3.

Table 5. The significance, stationarity, and weak exogeneity tests results.

\begin{tabular}{|c|c|c|c|}
\hline \multicolumn{4}{|c|}{ Panel A: Statistics for Testing the Significance of a Given Variable in the Cointegrating Space } \\
\hline & $E$ & $p$ & $g d p$ \\
\hline$\chi^{2}(1)$ & $17.774^{* * *}$ & $14.688^{* * *}$ & $18.714^{* * *}$ \\
\hline \multicolumn{4}{|c|}{ Panel B: Multivariate Statistics for Testing Stationarity ${ }^{b}$} \\
\hline & $E$ & $p$ & $g d p$ \\
\hline$x^{2}(2)$ & $22.129^{* * *}$ & $29.215^{* * *}$ & $26.452 * * *$ \\
\hline \multicolumn{4}{|c|}{ Panel C: Weak Exogeneity Test Statistics ${ }^{c}$} \\
\hline & $E$ & $p$ & $g d p$ \\
\hline$\chi^{2}(1)$ & $19.152 * * *$ & 0.002 & $3.499 *$ \\
\hline
\end{tabular}

Notes: ${ }^{a}$ the null hypothesis is that given variable is statistically insignificant; ${ }^{b}$ the null hypothesis is that given variable is (trend) stationary; ${ }^{c}$ the null hypothesis is that given variable is weakly exogenous; ${ }^{*}$ and ${ }^{* * *}$ denote rejection of the null hypotheses at the $10 \%$ and $1 \%$ significance levels, respectively; Estimation period: 1997-2013. 
The results reported in Panel C of Table 5 suggest that $p$ and $g d p$ are weakly exogenous to the cointegration relationship at the $5 \%$ significance level, whereas $e$ is not weakly exogenous. Using the $10 \%$ significance level, $g d p$ also becomes not weakly exogenous. However, the joint test on the loading (speed of adjustment) coefficients in the $\Delta p$ and the $\Delta g d p$ equations produce sample values of 3.62 for the $\chi^{2}$ distribution with a probability of 0.16 , thus leading to the conclusion that both $p$ and $g d p$ are weakly exogenous to the cointegration relationship. This all implies that it is acceptable to proceed from the VECM to the single equation ECM analysis (as discussed in [61] inter alia).

It is worth highlighting that the cointegration analysis using the Johansen approach was conducted first because it outperforms all its alternatives in correctly determining the number of cointegrated relationships in the case of more than two variables. The Johnsen test indicated that there is only one cointegrating relationship among the variables. Then, as a robustness check, the ARDLBT was also run for the same purpose. The results (which are not reported here, but are obtainable from the authors under request) also indicate that there is a cointegrating relationship among the variables, which suggest that the cointegration test results from the Johansen approach are robust.

Given that the Johansen test concluded that there was no more than one cointegrated relationship between the variables, the ARDLBT, FMOLS, DOLS and CCR methods are also be employed alongside the VECM in estimating the long- and short-run coefficients. Note that a maximum lag order of two is set when running the ARDLBT estimation, similar to that for the VAR. The optimum lag order for the dependent variable and the regressors being selected by the Schwarz criterion, which is the more relevant information criterion in the case of small samples. For the DOLS estimation, a maximum of one lag and one lead was set as for the VECM, with the optimal order selected by the Schwarz criterion for the same reason.

Since there is no dynamic part in the FMOLS and CCR estimations, two pulse dummies are included for 2007, in order to capture the sharp decline in electricity consumption for that year. A time trend was also included in the ARDLBT, FMOLS, DOLS, and CCR to capture technological and other changes, which is not accounted for explicitly, however, like the Johansen estimation, it proved to be insignificant in all estimators and hence was excluded. Table 6 presents the results from these five different procedures and shows that they all produce statistically significant coefficients that are very close; moreover, the residuals from the ARDLBT, DOLS, FMOLS and CCR estimations successfully pass the residuals diagnostics tests-another indication of the robustness of the estimation results (these results are not reported here, but are available from the authors on request). Furthermore, the estimated long-run coefficients are very similar across all the procedures, suggesting that the long-run price and income elasticities of electricity demand are between -1.0 to -0.8 and 0.1 to 0.2 , respectively. In fact, the VECM, the ARDLBT, the DOLS and the CCR all produce estimated price and income elasticities of about -1.0 to -0.9 and 0.2 , respectively - the FMOLS estimates being the slight outliers at -0.8 and 0.1 , respectively.

Table 6. Long-run elasticities from the methods.

\begin{tabular}{cccc}
\hline \multirow{2}{*}{ Methods } & $p$ & $g d p$ & Intercept \\
\cline { 2 - 4 } & Coef. (Std. Er.) & Coef. (Std. Er.) & Coef. (Std. Er.) \\
\hline VECM & $-0.950(0.084)^{* * *}$ & $0.191(0.031)^{* * *}$ & $-4.148(0.562)^{* * *}$ \\
ARDLBT & $-0.994(0.09)^{* * *}$ & $0.204(0.034)^{* * *}$ & $-4.401(0.536)^{* * *}$ \\
DOLS & $-0.894(0.078)^{* * *}$ & $0.174(0.028)^{* * *}$ & $-3.909(0.425)^{* * *}$ \\
FMOLS & $-0.788(0.118)^{* * *}$ & $0.143(0.052)^{* * *}$ & $-3.264(0.717)^{* * *}$ \\
CCR & $-0.984(0.145)^{* * *}$ & $0.207(0.059)^{* * *}$ & $-4.398(0.864)^{* * *}$ \\
\hline
\end{tabular}

Notes: The dependent variable is $e$; Coef. and Std. Er. mean coefficient and standard error; ${ }^{* * *}$ denotes rejection of the null hypothesis at the 1\% significance level. Estimation period covers 1997-2013.

Finally, the single equation ECMs were estimated using the General to Specific modeling strategy outlined in the methodological section. The general specifications included an intercept 
term, contemporaneous and one lagged values of $\Delta p, \Delta g d p, h d d, c d d$, one-lagged values of the ECTs, and the $\Delta e$. The resulting final specifications found by the estimation strategy outlined above and test statistics are reported in Table 7. This shows that the SoA coefficients across all the methods are negative and statistically significant; indicating that the short-run disequilibrium adjusts to the long-run equilibrium path and therefore, the cointegrating relation among the variables is stable. Additionally, the estimates are very close to each other, generally being about -0.9 , although again the FMOLS estimates are an outlier, given the estimated SoA is about -1.0 .

Table 7. Final Error Correction Model Specifications from the methods.

\begin{tabular}{|c|c|c|c|c|c|}
\hline Method & Johansen & ARDLBT & DOLS & CCR & FMOLS \\
\hline \multicolumn{6}{|c|}{ Panel A: The final ECM Specifications } \\
\hline Regressor & Coef. (Std. Er.) & Coef. (Std. Er.) & Coef. (Std. Er.) & Coef. (Std. Er.) & Coef. (Std. Er.) \\
\hline ect_Joht-1 & $-0.921(0.100) * * *$ & - & - & - & - \\
\hline ect_ARDLBT $T_{t-1}$ & - & $-0.879(0.097)^{* * *}$ & - & - & - \\
\hline$e c t \_D O L S_{t-1}$ & - & - & $-0.969(0.108) * * *$ & - & - \\
\hline ect_CCR $R_{t-1}$ & - & - & - & $-0.892(0.098) * * *$ & - \\
\hline ect_FMOLS $S_{t-1}$ & - & - & - & - & $-1.025(0.140)^{* * *}$ \\
\hline$c$ & $-0.039(0.028)$ & $-0.022(0.028)$ & $0.026(0.026)$ & $-0.009(0.027)$ & $-0.038(0.035)$ \\
\hline$\Delta p_{t}$ & $-0.367(0.044)^{* * *}$ & $-0.373(0.045)^{* * *}$ & $-0.356(0.045)^{* * *}$ & $-0.372(0.045)^{* * *}$ & $-0.324(0.051)^{* * *}$ \\
\hline$\Delta p_{t-1}$ & $0.328(0.051)^{* * *}$ & $0.330(0.052) * * *$ & $0.321(0.052) * * *$ & $0.331(0.053) * * *$ & $0.295(0.061)^{* * *}$ \\
\hline$\Delta g d p_{t-1}$ & $0.483(0.285)$ & $0.402(0.283)$ & $0.580(0.299)^{*}$ & $0.412(0.285)$ & $0.707(0.371) *$ \\
\hline \multicolumn{6}{|c|}{ Panel B: Statistics, Residuals Diagnostics and Misspecification tests results } \\
\hline$\hat{\delta}$ & 0.0331 & 0.0335 & 0.0339 & 0.0336 & 0.0403 \\
\hline AIC & -3.738 & -3.717 & -3.689 & -3.710 & -3.345 \\
\hline SBC & -3.493 & -3.472 & -3.444 & -3.465 & -3.100 \\
\hline$F_{A R}$ & $0.196[0.826]$ & 0.258 [0.777] & 0.064 [0.939] & $0.257[0.778]$ & $0.260[0.776]$ \\
\hline$F_{A R C H}$ & $0.538[0.475]$ & $0.516[0.485]$ & $0.774[0.394]$ & $0.420[0.528]$ & $3.636[0.077]^{*}$ \\
\hline$F_{H E T R}$ & $0.333[0.851]$ & $0.324[0.857]$ & $0.405[0.802]$ & $0.332[0.851]$ & $0.936[0.476]$ \\
\hline$J B_{N}$ & $3.957[0.138]$ & $4.144[0.126]$ & $2.554[0.279]$ & 3.910 [0.142] & $1.259[0.533]$ \\
\hline$F_{F F}$ & $0.178[0.681]$ & $0.146[0.710]$ & $0.426[0.528]$ & $0.221[0.647]$ & $2.236[0.163]$ \\
\hline
\end{tabular}

Notes: Dependent variable is $\triangle e_{t}$; ect_Joh, ect_ARDLBT, ect_DOLS, ect_CCR, and ect_FMOLS are the error correction terms, i.e., the residuals from the long-run relations from the Johnsen, ARDLBT, DOLS, CCR and FMOLS estimations; $\hat{\delta}$ is standard error of regression; $F_{A R}, F_{A R C H}$ and $F_{H E T R}$ denote $F$ statistics to test the null hypotheses of no serial correlation, no autoregressive conditioned heteroscedasticity, and no heteroscedasticity in the residuals; $J B_{N}$ and $F_{F F}$ indicate and Jarque-Bera and $F$ statistics to test the null hypotheses of normal distribution and no functional form miss-specification, respectively; Coef. and Std. Er. denote coefficient and standard error; Probabilities in brackets; ${ }^{*}$ and ${ }^{* * *}$ denote rejection of the null hypotheses at the $10 \%$ and $1 \%$ significance levels, respectively; Estimation period: 1997-2013.

\subsection{Discussion of the Estimation Results}

The UR test results suggest that the natural logarithms of electricity consumption per capita, Non-oil GDP per capita and the real electricity price are non-stationary in levels, but stationary in first difference, i.e., they are all I(1) processes. This means that they are trending and thereby do not return to their mean and the mean is changing over time. This implies that future values of the variables form randomly and thus are difficult to predict and any shock to the variables would have a permanent effect. However, the UR tests for the natural logarithms of heating degree days and cooling degree days suggest that they are both stationary in levels, i.e., they are both $\mathrm{I}(0)$ processes.

The results from the Johnsen cointegration tests suggest that there is a common trend among the trending, I(1), variables and that the cointegration between the per capita electricity consumption, Non-oil GDP per capita and, real electricity prices implies that the relationship between their levels is not spurious-thus the coefficients from this relationship are suitable for analysis and forecasting. Moreover, it provides acceptable estimated (constant) elasticities (since the variables are in natural logarithms) for the variables of interest from the five different estimators employed: Johansen, ARDL, DOLS, CCR and FMOLS. Thus, the estimated long-run price elasticity of per capita electricity demand is found to be around -0.9 , which is a relatively strong response although still suggesting that per capita electricity demand in Azerbaijan is inelastic - i.e., ceteris paribus, a 1\% rise in the real electricity price leads to a $0.9 \%$ decrease in per capita electricity demand in the long run. The estimated income elasticity of electricity demand however is found to be more inelastic at around 0.2 -i.e., ceteris paribus, 
a $1 \%$ increase in the per capita Non-oil GDP leads a $0.2 \%$ increase in per capita electricity demand in the long run. This is somewhat lower than the assumed income elasticities in the reports that produced forecasts of electricity demand for Azerbaijan discussed in the literature review.

The estimated final five ECM specifications demonstrate economically meaningful findings with the estimated SoA coefficients being very close across the different estimators, with the average being -0.94 , suggesting fast adjustment of over $90 \%$ of any disequilibrium in per capita electricity demand "corrected" within a year. (Although the FMOLS estimates suggest a slight overcorrection since the estimated SoA coefficient is larger than -1 (in absolute terms), so that the adjustment process back to equilibrium path is sooner than one year.) These estimates therefore suggest that electricity system in Azerbaijan is 'reform friendly', in that if policy makers implement changes to the system, the effects of the shock (such as a large price increase) will be absorbed very quickly.

Turning to the ECM results, the estimated short-run per capita electricity price elasticity is found to be -0.4 for the Johansen, ARDLBT, DOLS and CCR, estimates but slightly lower (in absolute terms) for the FMOLS estimates at -0.3 . Thus, as would be expected, the price elasticity is smaller (in absolute terms) than in the long run; however, this is not the case for the income elasticity. The estimated short-run income elasticities are 0.4 for ARDLBT and CCR, 0.5 for Johansen, 0.6 for DOLS, and for FMOLS, somewhat larger at 0.7-a similar relationship between the short-run and the long-run income elasticities found for UK total energy demand by [85].

Finally, in terms of the weather variables, which were found to be $\mathrm{I}(0)$ and therefore only considered for the short-run ECM, both $c d d$ and $h d d$ were found to be not statistically significant and hence excluded from the final ECM specifications. For cooling degree-days this is not surprising given Azerbaijan's climate and similarly for heating degree-days, given it is natural gas and diesel (particularly in rural areas) —not electricity—that are primarily used for heating purposes. These results are similar to $[48,91]$ who found heating and cooling degree-day variables to be insignificant in their electricity demand estimation.

\section{Projections of Future Paths of the Electricity Demand}

The previous section detailed the estimation for the various cointegration models of per capita electricity demand for Azerbaijan. This section builds on the estimated models by firstly, describing the forecast methodology adopted, secondly, by stating and describing the forecast assumptions, and finally by presenting the projected forecast scenarios for electricity demand (denoted by ET).

\subsection{Methodology}

There is a vast literature on economic forecasting; among others, [95] discusses the understanding of economic forecasts, [96] shows strategies and techniques in econometric forecasting, and [97] describes elements of forecasting, while [98-100] all document the different aspects of forecasting economic time series. In general, economic forecasting methods can be classified into three groups [101]: causal methods (univariate and multivariate regression analysis); time series methods for only one variable (autoregressive, moving average, autoregressive integrated moving average, exponential smoothing, and trend); and qualitative methods (such as Delphi method, Jury of Executive Opinion etc.). The first two methods are widely used in forecasting economic time series, depending on the forecast question. In this paper, the causal method is employed, via cointegration analysis. In particular, the ECM specifications developed based on different cointegration approaches presented in Table 7 are utilized to produce forecast values of electricity demand for Azerbaijan over the period 2014-2025. The advantages of the ECM compared to other forecasting models are discussed by [102-104] among others discuss. One advantage of using the ECM approach is that by incorporating the short-run dynamics with a long-run equilibrium relationship, they provide more information and thereby likely to produce more accurate forecasts. Another advantage is that they predict future values of the variable of interest based on future paths of its determinants, thus making them a useful tool in policy scenario 
analysis and decision-making. The next section therefore details the assumptions made about the determinants of electricity demand in Azerbaijan in order to produce the forecast scenarios.

\subsection{Forecast Assumptions}

The explanatory variables in the final ECM specifications, reported in Table 7, are per capita real Non-oil GDP and the real electricity price; hence, assumptions about these variables in the future are required in order to predict future values for, initially, per capita electricity demand. In order to derive these assumptions and to provide future values for electricity demand (rather than per capita electricity demand) assumptions are required for population, real Non-oil GDP, the nominal electricity price, and CPI over the period 2014-2025. However, the actual values for these variables are already known for 2014 and 2015, so these are used with assumptions for 2016 onwards based on three scenarios: Business as Usual, "high" (as in high electricity demand) "low" (as in low electricity demand). The assumptions about these variables are summarized in Table 8, which are based on a combination of statistical judgment and intelligence from various outlooks and strategic documents from the Azerbaijani government and international organizations.

The assumptions for real Non-oil GDP growth are based on the strategy of the Azerbaijani government [105] and the projections from [106-108]. The strategy targets growth of more than $7 \%$ per annum for real Non-oil GDP for each year until 2020. Considering that macroeconomic environment for the Non-oil sector development will not be as favorable as over the past years due to the drop in oil revenues (caused by relatively low oil price and sharp decrease in oil reserves in future) and thus government spending. It is therefore assumed that growth will be $8 \%$ per annum in the "high" scenario. Azerbaijan Non-oil GDP is projected by [4] to grow by 3.8\% and 3.9\% per annum, respectively in 2016 and 2017, whereas [107,108] forecasts around 2\% growth for 2017. Hence, the assumptions here for real Non-oil GDP growth for the Business as Usual and "low" scenarios are $4 \%$ and $2 \%$ per annum, respectively.

Table 8. Assumptions on the Variables across Scenarios, 2016-2025.

\begin{tabular}{cccc}
\hline Variable & \multicolumn{3}{c}{ Scenarios } \\
\cline { 2 - 4 } & “High" Scenario & Business as Usual & “Low” Scenario \\
\hline $\begin{array}{c}\text { Non-oil GDP, million } \\
\text { AZN 2005 prices }\end{array}$ & $8 \%$ growth (Based on [105]) & $\begin{array}{c}4 \% \text { growth (Based on projections } \\
\text { from [108]) }\end{array}$ & $\begin{array}{c}2 \% \text { growth (Based on projections } \\
\text { from [106,107]) }\end{array}$ \\
\hline Population, millions & $\begin{array}{c}1.0 \% \text { growth (High Variant } \\
\text { from [109]) }\end{array}$ & $\begin{array}{c}0.7 \% \text { growth (Medium Variant } \\
\text { from [109]) }\end{array}$ & $\begin{array}{c}0.5 \% \text { growth (Low Variant } \\
\text { from [109]) }\end{array}$ \\
\hline $\begin{array}{c}\text { Consumer price index, } \\
\%, \text { 2005 = 100 }\end{array}$ & $\begin{array}{c}8 \% \text { growth (Based on projections } \\
\text { from [106,110-114]) }\end{array}$ & $\begin{array}{c}4 \% \text { growth (Based on average } \\
\text { growth rate of 2009-2013) }\end{array}$ & $\begin{array}{c}2 \% \text { growth (Based on projections } \\
\text { from [106,110-114]) }\end{array}$ \\
\hline $\begin{array}{c}\text { Electricity price, AZN } \\
\text { per kwh }\end{array}$ & $\begin{array}{c}\text { \% growth (Based on making } \\
\text { nominal prices unchanged) }\end{array}$ & $\begin{array}{c}4 \% \text { growth (Based on making } \\
\text { real prices unchanged) }\end{array}$ & $\begin{array}{c}17 \% \text { increase in 2016, 34\% } \\
\text { increase in 2019 and 68\% in 2022 }\end{array}$ \\
\hline
\end{tabular}

For population growth, the [109] Projections for Azerbaijani population are utilized; their Medium Variant, High Variant and Low Variant are used for the Business as Usual, "high" and "low" scenarios, receptively with the population in Azerbaijan assumed to grow on average at $0.7 \%, 1.1 \%$ and $0.5 \%$ per annum, respectively over the period 2016 to 2025 (calculated using the compound growth rate formula).

For the Azerbaijani CPI there are three development stages: 1996-2003, 2004-2008, and 2009 onwards. These stages of inflation are consistent with the development stages of the Azerbaijani economy as discussed in [110]. Average inflation was around $4 \%$ in the post-crisis recovery period, 2009-2013; therefore, for the Business as Usual scenario, it is assumed that the development path of inflation in the post-crisis recovery period will continue in the projected period at $4 \%$ per annum. However, for the "high" and "low" scenarios it is assumed that annual inflation would be $8 \%$ and $2 \%$ per annum, respectively for the 2016-2025 period, which are based on various projections from $[4,106,111-114]$. 
Finally, to obtain assumptions for the real electricity price, assumptions are required for the nominal electricity price in conjunction with the CPI assumptions above. For the "high" scenario, nominal electricity prices are assumed to remain unchanged at $0.06 \mathrm{AZN}$ per $\mathrm{kWh}$ (which results in the real electricity falling over the projection period given the $8 \%$ inflation rate assumed for this scenario). For the Business as Usual scenario, it is assumed that the nominal electricity price will rise in line with inflation (i.e., $4 \%$ per year) so that the real electricity price would be unchanged over the forecast period. For the "low" scenario, it is assumed that the government would increase the nominal price periodically. There was a 17\% increase in July 2016 (as discussed above) but in addition, it is assumed that further large increases are made after three years, i.e., 34\% in 2019 and $68 \%$ in 2022 . Table 9 details the projected values for the explanatory variables based on the assumptions discussed in this sub-section.

Table 9. Projected values for the explanatory variables.

\begin{tabular}{|c|c|c|c|c|c|c|c|c|c|c|c|c|}
\hline \multirow{2}{*}{ Year } & \multicolumn{3}{|c|}{ Population, Millions } & \multicolumn{3}{|c|}{$\begin{array}{l}\text { Non-oil GDP, Million AZN in } \\
2005 \text { Price }\end{array}$} & \multicolumn{3}{|c|}{$\begin{array}{l}\text { Consumer Price } \\
\text { Index, } 2005=100\end{array}$} & \multicolumn{3}{|c|}{$\begin{array}{l}\text { Electricity Price, } \\
\text { AZN per kwh }\end{array}$} \\
\hline & HS & BU & LS & HS & BU & LS & HS & BU & LS & HS & BU & LS \\
\hline 2014 & 9.54 & 9.54 & 9.54 & $20,789.71$ & $20,789.71$ & $20,789.71$ & 185.53 & 185.53 & 185.53 & 0.06 & 0.06 & 0.06 \\
\hline 2015 & 9.65 & 9.65 & 9.65 & $22,800.40$ & $22,800.40$ & $22,800.40$ & 192.95 & 192.95 & 192.95 & 0.06 & 0.06 & 0.06 \\
\hline 2016 & 9.88 & 9.87 & 9.86 & & $23,712.41$ & & 208.39 & 200.67 & 196.81 & 0.06 & 0.06 & 0.07 \\
\hline 2017 & 10.00 & 9.97 & 9.94 & $26,594.39$ & $24,660.91$ & $23,721.53$ & 225.06 & 208.70 & 200.75 & 0.06 & 0.07 & 0.07 \\
\hline 2018 & 10.12 & 10.07 & 10.02 & $28,721.94$ & $25,647.35$ & $24,195.97$ & 243.06 & 217.05 & 204.76 & 0.06 & 0.07 & 0.07 \\
\hline 2019 & 10.23 & 10.16 & 10.09 & $31,019.69$ & $26,673.24$ & $24,679.88$ & 262.51 & 225.73 & 208.86 & 0.06 & 0.07 & 0.09 \\
\hline 2020 & 10.34 & 10.24 & 10.14 & $33,501.27$ & $27,740.17$ & $25,173.48$ & 283.51 & 234.76 & 213.04 & 0.06 & 0.07 & 0.09 \\
\hline 2021 & 10.44 & 10.32 & 10.19 & 36,1 & $28,849.78$ & $25,676.95$ & 306.19 & 244.15 & 217.30 & 0.06 & 0.08 & 0.09 \\
\hline 2022 & 10.53 & 10.38 & 10.23 & $39,075.88$ & $30,003.77$ & $26,190.49$ & 330.69 & 253.91 & 221.64 & 0.06 & 0.08 & 0.16 \\
\hline 2023 & 10.62 & 10.44 & 10.27 & $42,201.95$ & $31,203.92$ & $26,714.30$ & 357.14 & 264.07 & 226.07 & 0.06 & 0.08 & 0.16 \\
\hline 2024 & 10.70 & 10.50 & 10.30 & $45,578.10$ & $32,452.08$ & $27,248.59$ & 385.71 & 274.63 & 230.60 & 0.06 & 0.09 & 0.16 \\
\hline 2025 & 10.78 & 10.55 & 10.32 & $49,224.35$ & $33,750.16$ & $27,793.56$ & 416.57 & 285.62 & 235.21 & 0.06 & 0.09 & 0.16 \\
\hline
\end{tabular}

\subsection{Forecast Scenarios and Discussion}

Given the assumptions described in the previous section, electricity demand in Azerbaijan is projected for the three scenarios over the period 2014 to 2025 by employing the final ECM specifications for the five different cointegration methods, using the assumed future values for the determinants outlined in Table 9. However, before discussing the forecast scenario results, it is useful to consider the in sample forecast performance of the final preferred ECM specifications. Figure 3 therefore compares the in sample forecast values of electricity demand for the five final ECM specifications with actual electricity consumption in Azerbaijan over the estimation period 1997 to 2013 and Table 10 gives the summary forecast statistics for the same period.

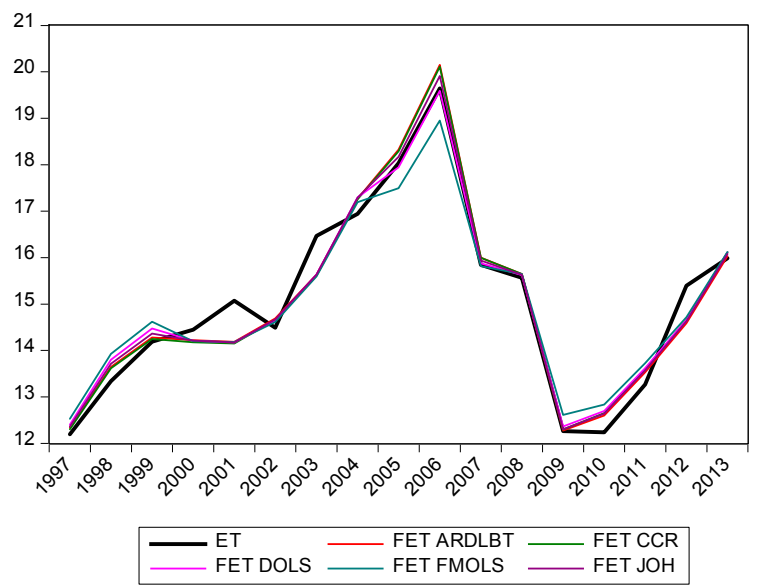

Figure 3. Actual and forecast (in sample) electricity demand, TWh. 
Table 10. Forecast statistics of Error Correction Models.

\begin{tabular}{cccccc}
\hline \multirow{2}{*}{ Statistic } & \multicolumn{5}{c}{ Final ECM Specifications } \\
\cline { 2 - 6 } & Johansen & ARDLBT & DOLS & CCR & FMOLS \\
\hline Root Mean Squared Error & $0.410^{\# \#}$ & 0.422 & $0.417^{\#}$ & 0.422 & 0.502 \\
Mean Absolute Error & $0.316^{\# \#}$ & 0.325 & $0.320^{\#}$ & 0.327 & 0.430 \\
Mean Abs. Percent Error & $2.108^{\# \#}$ & $2.126^{\#}$ & 2.183 & 2.147 & 2.891 \\
Theil Inequality Coefficient & $0.013536^{\# \#}$ & 0.013924 & $0.013785^{\#}$ & 0.013910 & 0.016605 \\
Bias Proportion & 0.000210 & $0.000007^{\#}$ & 0.001382 & $0.000002^{\# \#}$ & 0.005110 \\
Variance Proportion & $0.001463^{\# \#}$ & 0.011423 & 0.059960 & $0.006865^{\#}$ & 0.338458 \\
Covariance Proportion & $0.998327^{\# \#}$ & 0.988570 & 0.938658 & $0.993133^{\#}$ & 0.656431 \\
\hline
\end{tabular}

Note: \#\# indicates the "best model" and " the "second best model" as suggested by the given statistics where the smallest value indicates the best model other than for the Covariance Proportion where the best model is given by the largest value for the statistic.

It should be noted that, although the estimated ECM specifications are based on per capita electricity demand, for forecast purposes the models are re-formulated to produce forecasts of Azerbaijani electricity demand (ET) denoted by FET-hence Figure 3 is also for electricity demand. Figure 3 shows that in general, all five cointegration ECM specifications do a good job in predicting the various turning points during the estimation period. They all produce consistent (in sample) forecast values although none captures adequately the sharp increases in 2001, 2003 and 2012. Dummy variables could be included in the specifications for these years to help capture these spikes; however, this was not done given there was no a-priori socio-economic or other explanations for including these-unlike the 2007 dummy that was included.

Table 10 reports seven forecast statistics and it shows that generally, the ECM specification derived from the Johansen approach outperforms all its counterparts. The second best model is less clear-cut, but generally, the statistics suggest that the ECMs from the CCR and DOLS methods are the second best. However, all the ECM specifications perform well in terms of forecast error statistics as well as Bias and Covariance Proportions as they have very little error in their forecast while bias from the actual values is very small and the covariance between actual and forecast values is quite high, more than $93 \%$, except for FMOLS. Therefore, instead of considering only the best performing specification and producing single out of sample forecasts, five sets of forecast scenarios are produced using all the estimated ECM specifications in order to compare how they perform and to obtain a forecast range.

Figure 4 illustrates the five projected paths of electricity consumption in Azerbaijan for 2014-2025 (where the red, green, and grey lines indicate projected values from the "high", Business as Usual and "low" scenarios, respectively) and shows that all the specifications produce quite close forecasts. This is clearly shown in Figure 5, (which brings together all scenarios projections) and Table 11, which details the forecast electricity demand scenarios for all specifications (highlighting the range of the Business of Usual forecast as well as the highest "high" scenario and the lowest "low" scenario). These show that the range of the Business as Usual scenarios is relatively small-for 2025 the forecasts suggest that electricity demand in Azerbaijan would be between just under $19 \frac{1}{2} \mathrm{TWh}$ (given by the FMOLS forecast) and almost 21 TWh (given by the CCR forecast). However the models suggest that electricity demand in 2015 in Azerbaijan could be as high as about $45 \frac{1}{2}$ TWh or as low as about 9 TWh (both given by the ARDLBT model) according to the "high" and "low" scenarios, respectively. Thus, in general the models themselves give very similar forecasts based on the same assumptions; however, the different forecast assumptions produce quite a wide variation of forecasts for all models. 

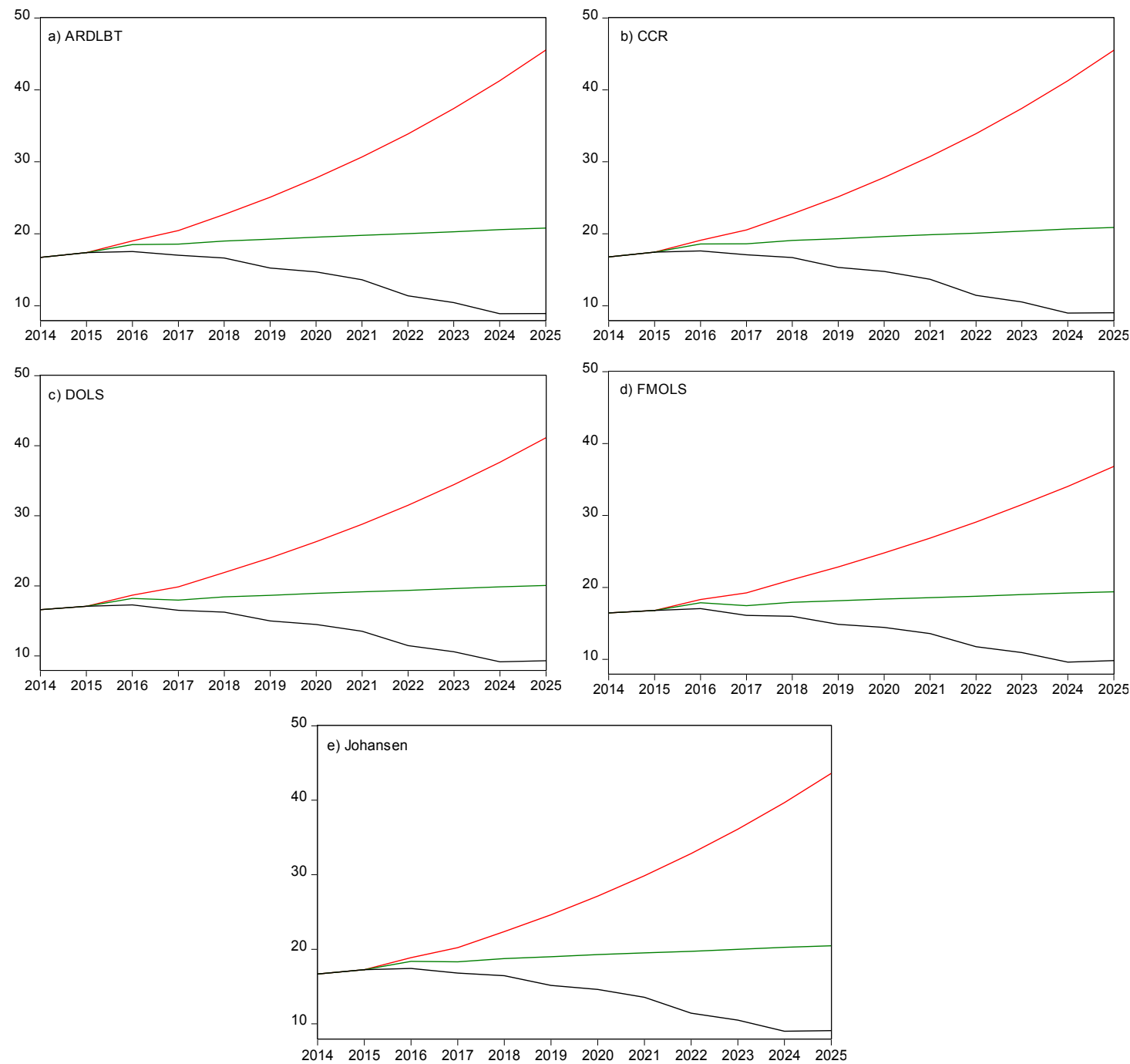

Figure 4. Projected time paths of the electricity consumption, TWh. (Note: the red, green, and grey lines indicate projected values from the "high", Business as Usual and "low" scenarios, respectively).
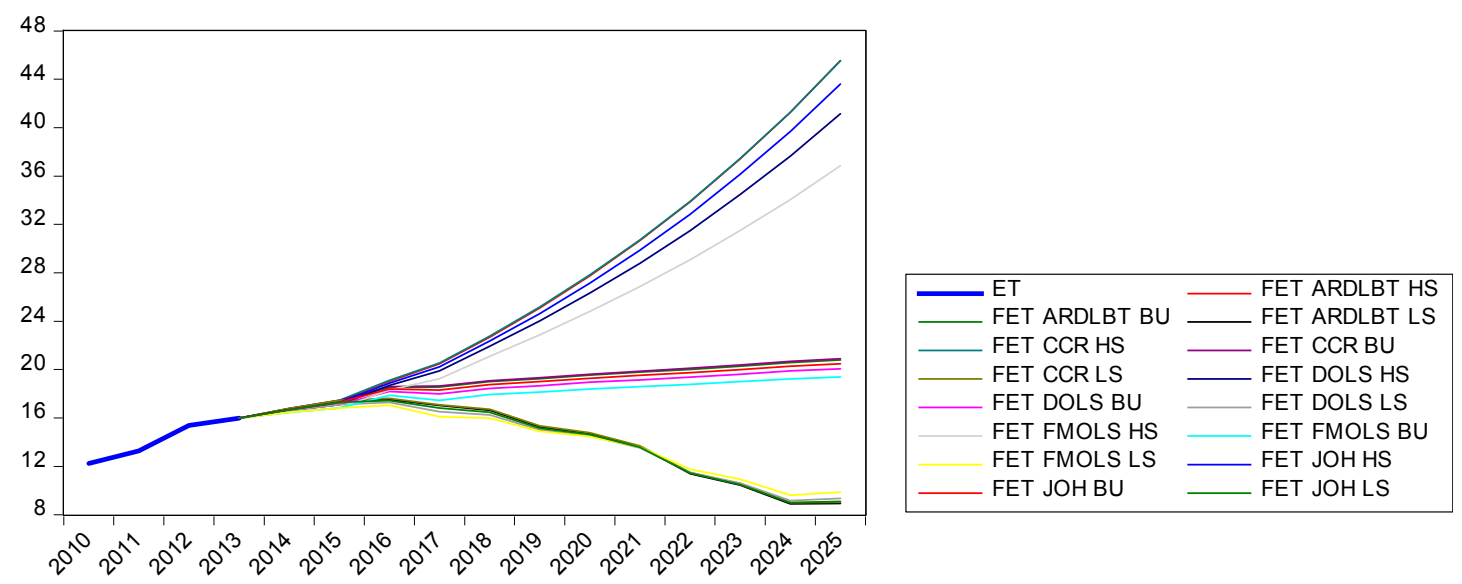

Figure 5. Combined projected time paths of the electricity consumption, TWh. 
Table 11. Projected electricity consumption, TWh.

\begin{tabular}{cccccc}
\hline Method & Scenario & $\mathbf{2 0 1 3}$ & $\mathbf{2 0 1 5}$ & $\mathbf{2 0 2 0}$ & $\mathbf{2 0 2 5}$ \\
\hline \multirow{3}{*}{ ARDLBT } & HS & 15.985 & 17.390 & 27.761 & 45.542 \\
& BU & 15.985 & 17.390 & 19.550 & 20.802 \\
& LS & 15.985 & 17.390 & 14.707 & 8.929 \\
\hline \multirow{2}{*}{ CCR } & HS & 15.985 & 17.461 & 27.832 & 45.523 \\
& BU & 15.985 & 17.461 & 19.626 & 20.893 \\
& LS & 15.985 & 17.461 & 14.783 & 9.032 \\
\hline \multirow{2}{*}{ DOLS } & HS & 15.985 & 17.097 & 26.317 & 41.149 \\
& BU & 15.985 & 17.097 & 18.941 & 20.069 \\
FMOLS & LS & 15.985 & 17.097 & 14.514 & 9.332 \\
& HS & 15.985 & 16.802 & 24.798 & 36.844 \\
& LS & 15.985 & 16.802 & 18.393 & 19.400 \\
Johansen & HS & 15.985 & 16.802 & 14.447 & 9.848 \\
& BU & 15.985 & 17.270 & 27.145 & 43.608 \\
\hline HS MAX & & 15.985 & 17.270 & 19.284 & 20.483 \\
BU MAX & & 15.985 & 17.461 & 27.832 & 45.542 \\
BU MIN & & 15.985 & 17.461 & 19.626 & 20.893 \\
LS MIN & & 15.985 & 16.802 & 18.393 & 19.400 \\
\hline
\end{tabular}

Note: HS, BU and LS mean "high", Business as Usual and "low" scenarios, respectively; Bold green and bold red indicate maximum projected values in "high" and Business as Usual scenarios; while bold blue and bold purple show minimum projected values in the Business as Usual and "low" scenarios.

It interesting to compare the projected values from this research with those from the reports discussed in Section 2. Reference [14] projects electricity demand in Azerbaijan for 2025 to be 42 TWh by assuming $5.1 \%$ annual growth rate of GDP for 2020-2025 and the projection from [15] is also close to this value. Additionally, [13] forecasts the electricity demand to be $31.4 \mathrm{TWh}, 34.8 \mathrm{TWh}$ and 44.8 TWh, respectively in 2025 in their slow, central and high scenarios, assuming that GDP grows at $4 \%$ per annum across all three scenarios over the 2013-2025 period, but with different income elasticities of electricity demand of 0.8 in slow scenario and 1.5 in the high scenario. In terms of magnitude, their projected values (42 TWh and $44.8 \mathrm{TWh}$ ) are close to that of the projected values in the "high" scenario produced here, shown in Table 11. However, in terms of the assumptions on the income growth rate, the projected values from $[13,14]$ should be compared with the Business as Usual scenario here, where real Non-oil GDP is assumed to grow by $4 \%$ per annum. In doing so, it can be seen that their forecast values, including the value for the slow scenario in [13], are quite higher than even the maximum value from the Business as Usual scenario here. The projected higher values being the result of a number of factors, such as, not considering prices-one of the key determinants of electricity demand, their greater income elasticities, their use of total GDP, not Non-oil GDP, and in all probability their less sophisticated methodology.

\section{Summary and Conclusions}

This paper attempts to model Azerbaijan electricity demand and provide future forecast scenarios using cointegration techniques and is, as far as is known, the first to attempt to do this for Azerbaijan using such a comprehensive modelling framework. In addition, unlike the majority of countrywide energy demand studies, real Non-oil GDP is used as the income driver given that total GDP is overly influenced by volatile oil prices. At the end of the introductory section, a number of research questions were articulated and it is useful here to re-visit them and summarize exactly what has been achieved by the research. Therefore, each research question will be considered in turn.

- What is the best cointegration technique for modeling per capita electricity demand in Azerbaijan? 
Given that for all five cointegration methods considered for modeling per capita electricity demand in Azerbaijan passed the appropriate diagnostic tests, choosing the "best" is very difficult. That said the Johansen method is the "best" and the FMOLS method the "worst" according to a number of forecast statistics presented in Table 10-however there is very little difference between them; although the FMOLS model could be regarded as a marginal outlier given the estimated coefficients are a little different to the other four methods considered.

- What are the estimated price and income elasticities for per capita electricity demand in Azerbaijan?

The estimated electricity demand across the five methods vary very little. The estimated shortand long-run price elasticities range from -0.3 to -0.4 and -0.8 to -1.0 , respectively-suggesting that although the response to a real electricity price change is inelastic, it is relatively high, being close to unity in the long run. Whereas, the estimated short- and long-run income elasticities range from 0.4 to 0.7 and from 0.1 to 0.2 -which is also inelastic in both the short and the long run, but somewhat lower (in absolute terms) than the price elasticity in the long run.

- What do the future scenarios suggest for the development of electricity demand in Azerbaijan through to 2025 ?

Using the estimated ECM models for all five cointegration methods, coupled with assumptions about the relevant drivers of electricity demand, the Business as Usual scenario suggests that Azerbaijan electricity demand in 2025 would be something in the order of $19 \frac{1}{2}$ to $21 \mathrm{TWh}$; thus illustrating an average increase of about $0.6 \%$ per annum over the period from 2013 to 2025. Of course, different assumptions about the drivers suggest different demand in the future with the highest predicted electricity demand in 2025 being about $45 \frac{1}{2}$ TWh according to the "high" scenario or as low as about 9 TWh according to the "low" scenario.

This is therefore seen as a useful exercise in modeling electricity demand for Azerbaijan, a resource-rich country that has experienced rapid economic growth over a number of years with centrally administered energy prices, but with a limited number of time series observations.

Acknowledgments: We are grateful to Raj Ramasamy, three anonymous referees, and the editors for their comments and suggestions that have helped to improve considerably the paper; nonetheless, we are of course responsible for all errors and omissions. Finally, the views expressed in this paper are those of the authors and do not necessarily represent the views of their affiliated institutions.

Author Contributions: All authors contributed equally to all aspects of the research reported in this paper.

Conflicts of Interest: The authors declare no conflict of interest.

\section{References}

1. Filippini, M.; Hunt, L.C. Measurement of energy efficiency based on economic foundations. Energy Econ. 2015, 52, S5-S16. [CrossRef]

2. Enerdata. 2016. Available online: http://www.enerdata.net/enerdatauk/knowledge/subscriptions/ database/ (accessed on 10 May 2016).

3. Hasanov, F.C. Dutch Disease and the Azerbaijan Economy. J. Communist Post-Communist Stud. 2013, 4, 463-480. [CrossRef]

4. World Bank. Word Development Indicators. 2016. Available online: http://www.worldbank.org (accessed on 10 May 2016).

5. Energy Charter Secretariat. In Depth Review of the Energy Efficiency Policy of Azerbaijan. 2013. Available online: http://www.energycharter.org/fileadmin/DocumentsMedia/IDEER/IDEER-Azerbaijan_2013_ en.pdf (accessed on 25 September 2016).

6. Energy Charter Secretariat. Follow-UP IN-DEPTH Review of the Investment Climate and Market Structure in the Energy Sector. 2011. Available online: http://www.energycharter.org/fileadmin/DocumentsMedia/ ICMS/ICMS-Azerbaijan_2011_en.pdf (accessed on 25 September 2016). 
7. Ministry of Industry and Energy of Azerbaijan. 2012. Available online: http://www.minenergy.gov.az/db/ 2011_senaye_tehlil.pdf (accessed on 25 September 2016).

8. International Energy Agency. Energy Statistics. Available online: www.iea.org (accessed on 10 May 2016).

9. State Agency of Statistics of Azerbaijan. Available online: http:/ / www.astat.org (accessed on 6 July 2016).

10. Opitz, P.; Kharazyan, A.; Pasoyan, A.; Gurbanov, M.; Margvelashvili, M. Sustainable Energy Pathways in the South Caucasus: Opportunities for Development and Political Choices; South Caucasus Regional Office of the Heinrich Boell Foundation: Tbilisi, Georgia, 2015.

11. Azerenerji Joint Stock Company. Electricity Forecast Report; Azerenerji: Baku, Azerbaijan, 2009.

12. Azerenerji Joint Stock Company. Electricity Forecast Report; Azerenerji: Baku, Azerbaijan, 2013.

13. Fichtner. Update of the Power Sector Master Plan of Azerbaijan 2013-2025; Fichtner: Stuttgart, Germany, 2013.

14. Mercados. Azerenerji Generation and Transmission Master Plan 2010-2025; Fichtner: Stuttgart, Germany, 2010.

15. Japan International Cooperation Agency, Tokyo Electric Power Services Co. Study for Electric Power Sector in Azerbaijan; Japan International Cooperation Agency (JICA): Tokyo, Japan; Tokyo Electric Power Services Co. (TEPSCO): Tokyo, Japan, 2013.

16. Squalli, J. Electricity consumption and economic growth: Bounds and causality analyses of OPEC members. Energy Econ. 2007, 29, 1192-1205. [CrossRef]

17. Narayan, P.K.; Smyth, R. Multivariate Granger causality between electricity consumption, exports and GDP: Evidence from a panel of Middle Eastern countries. Energy Policy 2009, 37, 229-236. [CrossRef]

18. Chang, Y.; Choi, Y.; Kim, C.S.; Miller, J.I.; Park, J.Y. Disentangling Temporal Patterns in Elasticities: A Functional Coefficient Panel Analysis of Electricity Demand. Energy Econ. 2016, in press. [CrossRef]

19. Eltony, M.N. The Sectoral Demand for Electricity in Kuwait. OPEC Rev. 1995, 19, 37-44. [CrossRef]

20. Al-Faris, A.R.F. The demand for electricity in the GCC countries. Energy Policy 2002, 30, 117-124. [CrossRef]

21. Klytchnikova, I. Methodology and Estimation of the Welfare Impact of Energy Reforms on Households in Azerbaijan. Ph.D. Thesis, University of Maryland, Gollege Park, MD, USA, 2006.

22. Al-Sahlawi, M.A. Forecasting the Demand for Electricity in Saudi Arabia. Energy J. 1990, 11, 119-126. [CrossRef]

23. Eltony, M.N.; Yousuf, H.M. The Structure of Demand for Electricity in the Gulf Cooperation Council Countries. J. Energy Dev. 1993, 18, 213-221.

24. Eltony, M.N.; Asraul, H. A Cointegrating Relationship in the Demand for Energy: The Case of Electricity in Kuwait. J. Energy Dev. 1997, 21, 293-301.

25. Diabi, A. The Demand for Electric Energy in Saudi Arabia: An Empirical Investigation. OPEC Rev. 1998, 22, 13-29. [CrossRef]

26. Al-Sahlawi, M.A. Electricity Planning with Demand Estimation and Forecasting in Saudi Arabia. Energy Stud. Rev. 1999, 9, 82-88.

27. Askari, A. Estimation of electricity demand for residential sector and its price and income elasticities. J. Barnameh Va Budjeh 2002, 63, 103. (In Farsi)

28. Amini Fard, A.; Estedlal, S. Estimation of residential demand for electricity in Iran, evidence from a cointegration approach. In Proceedings of the 18th International Power System Conference, Tehran, Iran, 18-20 October 2003. (In Farsi)

29. Atakhanova, Z.; Howie, P. Electricity demand in Kazakhstan. Energy Policy 2007, 35, 3729-3743. [CrossRef]

30. Eltony, M.N.; Al-Awadhi, M.A. The commercial sector demand for energy in Kuwait. OPEC Rev. 2007, 31, 17-26. [CrossRef]

31. Eltony, M.N.; Al-Awadhi, M.A. Residential energy demand: A case study of Kuwait. OPEC Rev. 2007, 31, 159-168. [CrossRef]

32. Pourazarm, E.; Cooray, A.V. Estimating and forecasting residential electricity demand in Iran. Econ. Model. 2013, 35, 546-558. [CrossRef]

33. Atalla, T.N.; Hunt, L.C. Modelling residential electricity demand in the GCC countries. Energy Econ. 2016, 59, 149-158. [CrossRef]

34. Bildirici, M.E.; Kayikci, F. Economic growth and electricity consumption in former Soviet Republics. Energy Econ. 2012, 34, 747-753. [CrossRef]

35. International Monetary Fund. World Economic Outlook Database. 2014. Available online: http://www.imf. org/external/pubs/ft/weo/2014/02/weodata/index.aspx (accessed on 10 May 2016). 
36. Bentzen, J.; Engsted, T. Short and long run elasticities in energy demand: A cointegration approach. Energy Econ. 1993, 15, 9-16. [CrossRef]

37. Silk, J.; Joutz, F. Short and long-run elasticities in US residential electricity demand: A co-integration approach. Energy Econ. 1997, 19, 493-513. [CrossRef]

38. Pesaran, H.; Smith, R.P.; Akiyama, T. Energy Demand in Asian Developing Economies; Oxford University Press: Oxford, UK, 1998.

39. Asafu-Adjaye, J. The relationship between energy consumption, energy prices and economic growth: Time series evidence from Asian developing countries. Energy Econ. 2000, 22, 615-625. [CrossRef]

40. Hossein, A.; Gudarzi, F.Y.; Asghari, G.E. The Relationship between Energy Consumption, Energy Prices and Economic Growth: Case Study (OPEC Countries). OPEC Energy Rev. 2012, 36, 272-286. [CrossRef]

41. Amarawickrama, H.A.; Hunt, L.C. Electricity demand for Sri Lanka: A time series analysis. Energy 2008, 33, 724-739. [CrossRef]

42. Hunt, L.C.; Judge, G.; Ninomiya, Y. Modelling Underlying Energy Demand Trends. In Energy in a Competitive Market: Essays in Honour of Colin Robinson; Hunt, L.C., Ed.; Edward Elgar Publishing: Cheltenham, UK, 2003; Chapter 9; pp. 140-174.

43. Hunt, L.C.; Judge, G.; Ninomiya, Y. Underlying trends and seasonality in UK energy demand: A sectoral analysis. Energy Econ. 2003, 25, 93-118. [CrossRef]

44. Amarawickrama, H.A.; Hunt, L.C. Sri Lanka electricity supply industry: A critique of the proposed reforms. J. Energy Dev. 2005, 30, 239-278.

45. Hasanov, F.C.; Bulut, C.; Suleymanov, E. Do population age groups matter in the energy use of the oil-exporting countries? Econ. Model. 2016, 54, 82-99. [CrossRef]

46. Atallah, T.; Gualdi, S.; Lanza, A. Enhanced degree days for energy-related applications KAPSARC Discussion PAPER, KS_1514-DP08A. 2015. Available online: https://www.kapsarc.org/wp-content/uploads/2015/10/ KS-1514-DP08A-A-global-degree-days-database-for-energy-related-applications_for-web.pdf (accessed on 1 October 2016).

47. Tariff (Price) Council of Azerbaijan Republic. Available online: http://www.tariffcouncil.gov.az/?/en (accessed on 9 December 2016).

48. Beenstock, M.; Goldinn, E.; Nabot, D. The demand for electricity in Israel. Energy Econ. 1999, 21, $168-183$. [CrossRef]

49. Harvey, A.C. Forecasting, Structural Time Series Models and the Kalman Filter; Cambridge University Press: Cambridge, UK, 1989.

50. Engle, R.F.; Granger, C.J. Co-integration and Error Correction: Representation, Estimation and Testing. Econometrica 1987, 55, 251-276. [CrossRef]

51. Dickey, D.; Fuller, W. Likelihood Ratio Statistics for Autoregressive Time Series with a Unit Root. Econometrica 1981, 49, 1057-1072. [CrossRef]

52. Phillips, P.B.; Perron, P. Testing for Unit Roots in Time Series Regression. Biometrika 1988, 75, 335-346. [CrossRef]

53. Perron, P. The Great Crash, the Oil Price Shock, and the Unit Root Hypothesis. Econometrica 1989, 57, 1361-1401. [CrossRef]

54. Perron, P. Dealing with Structural Breaks. In Econometric Theory, Palgrave Handbook of Econometrics; Patterson, K., Mills, T.C., Eds.; Palgrave Macmillan: London, UK, 2006; Volume 1, pp. 278-352.

55. Enders, W. Applied Econometrics Time Series; Wiley Series in Probability and Statistics; University of Alabama: Tuscaloosa, AL, USA, 2010.

56. Johansen, S. Statistical analysis of cointegration vectors. J. Econ. Dyn. Control 1988, 12, 231-254. [CrossRef]

57. Johansen, S.; Juselius, K. Maximum likelihood estimation and inference on cointegration with applications to the demand for money. Oxf. Bull. Econ. Stat. 1990, 52, 169-210. [CrossRef]

58. Johansen, S. Testing Weak Exogeneity and the Order of Cointegration in UK Money Demand Data. J. Policy Model. 1992, 14, 313-334. [CrossRef]

59. Johansen, S. Cointegration in Partial Systems and the Efficiency of Single-Equation Analysis. J. Econom. 1992, 52, 389-402. [CrossRef]

60. De Brouwer, G.; Ericsson, N.R. Modeling Inflation in Australia; Research Discussion Paper 9510, International Finance Discussion Paper 530; Reserve Bank of Australia: Sydney, Australia, 1995. 
61. De Brouwer, G.; Ericsson, N.R. Modeling Inflation in Australia. J. Bus. Econ. Stat. 1998, 16, 433-449. [CrossRef]

62. Johansen, S. A small sample correction for the test of cointegrating rank in the vector autoregressive model. Econometrica 2002, 70, 1929-1961. [CrossRef]

63. Reinsel, G.C.; Ahn, S.K. Vector autoregressive models with unit roots and reduced rank structure: Estimation, likelihood ratio test, and forecasting. J. Time Ser. Anal. 1992, 13, 353-375. [CrossRef]

64. Reimers, H. Comparisons of tests for multivariate cointegration. Stat. Pap. 1992, 33, 335-359. [CrossRef]

65. Pesaran, M.H.; Shin, Y.; Smith, R.J. Bound Testing Approaches to the Analysis of Level Relationships. J. Appl. Econom. 2001, 16, 289-326. [CrossRef]

66. Pesaran, H.M.; Shin, Y. An Autoregressive Distributed Lag Modeling Approach to Cointegration Analysis. In Econometrics and Economic Theory in the 20th Century: The Ragnar Frisch Centennial Symposium; Strom, S., Ed.; Cambridge University Press: Cambridge, UK, 1999.

67. Pesaran, H.M.; Pesaran, B. Working with Microfit 4.0: Interactive Econometric Analysis; Oxford University Press: Oxford, UK, 1997.

68. Narayan, P.K. An Econometric Model of Tourism Demand and a Computable General Equilibrium Analysis of the Impact of Tourism: The Case of the Fiji Islands. Ph.D. Thesis, Department of Economics, Monash University, Melbourne, Australia, 2004, unpublished.

69. Narayan, P.K. The Saving and Investment Nexus for China: Evidence from Cointegration Tests. Appl. Econ. 2005, 37, 1979-1990. [CrossRef]

70. Stock, J.H.; Watson, M.W. A simple estimator of cointegrating vectors in higher order integrated systems. Econometrica 1993, 61, 783-820. [CrossRef]

71. Saikkonen, P. Asymptotically efficient estimation of cointegrated regressions. Econom. Theory 1991, 7, 1-21. [CrossRef]

72. Saikkonen, P. Estimation and testing of cointegrated systems by an autoregressive approximation. Econom. Theory 1992, 8, 1-27. [CrossRef]

73. Wickens, M.R.; Breusch, T.S. Dynamic Specification, the Long-Run and the Estimation of Transformed Regression Models. Econ. J. 1988, 98, 189-205. [CrossRef]

74. Park, J.Y. Canonical Cointegrating Regressions. Econometrica 1992, 60, 119-143. [CrossRef]

75. Park, J.Y.; Phillips, P.B. Statistical Inference in Regressions with Integrated Processes: Part I. Econom. Theory 1988, 4, 468-497. [CrossRef]

76. Phillips, P.B.; Hansen, B.E. Statistical Inference in Instrumental Variables Regression with I(1) Processes. Rev. Econ. Stud. 1990, 57, 99-125. [CrossRef]

77. Phillips, P.B.; Loretan, M. Estimating Long-run Economic Equilibria. Rev. Econ. Stud. 1991, 58, 407-436. [CrossRef]

78. Charemza, W.W.; Deadman, D.F. New Directions in Econometric Practice; Edward Elgar: Cheltenham, UK, 1992.

79. Cuthbertson, K.; Hall, S.G.; Taylor, M.P. Applied Econometric Techniques; Simon and Schuster: New York, NY, USA; University of Michigan Press: Ann Arbor, MI, USA, 1992.

80. Inder, B. Estimating Long-run Relationships in Economics. J. Econom. 1993, 57, 53-68. [CrossRef]

81. Engle, R.F.; Yoo, B.S. Cointegrated Economic Time Series: An Overview with New Results. In Long-Run Economic Relationships: Readings in Cointegration; Engle, R.F., Granger, C.W.J., Eds.; Oxford University Press: New York, NY, USA, 1991.

82. Utkulu, U. How to Estimate Long-Run Relationships in Economics, an Overview of Recent Development. DEÜİİBF Dergisi 1997, 12, 39-48.

83. MacKinnon, J. Critical Values for Cointegration Test. In Long-Run Economic Relationships; Engle, R., Granger, C., Eds.; Oxford University Press: Oxford, UK, 1991.

84. MacKinnon, J. Numerical Distribution Functions for Unit Root and Cointegration Tests. J. Appl. Econom. 1996, 11, 601-618. [CrossRef]

85. Hunt, L.; Manning, N. Energy price- and income-elasticities of demand: Some estimates for the UK using the cointegration procedure. Scott. J. Political Econ. 1989, 36, 183-193. [CrossRef]

86. Banerjee, A.; Dolado, J.J.; Gailbraith, J.; Hendry, D. Co-integration, Error-Correction, and the Econometric Analysis of Non-Stationary Data; Advanced Texts in Econometrics; Oxford University Press: Oxford, UK, 1986. 
87. Campos, J.; Ericsson, N.R.; Hendry, D.F. General-to-specific Modeling: An Overview and Selected Bibliography, Board of Governors of the Federal Reserve System, International Finance Discussion Papers, 838. 2005. Available online: http://www.federalreserve.gov/pubs/ifdp/2005/838/ifdp838.pdf (accessed on 25 September 2016).

88. Ng, S.; Perron, P. Unit root test in ARMA models with data-dependent methods for the selection of the truncation lag. J. Am. Stat. Assoc. 1995, 90, 268-281. [CrossRef]

89. Newey, W.; West, K. Autocovariance lag selection in covariance matrix estimation. Rev. Econ. Stud. 1994, 61, 613-653. [CrossRef]

90. Rapanos, V.; Polemis, M. Energy demand and environmental taxes: The case of Greece. Energy Policy 2005, 33, 1781-1788. [CrossRef]

91. Polemis, M. Modeling industrial energy demand in Greece using cointegration techniques. Energy Policy 2007, 35, 4039-4050. [CrossRef]

92. Johansen, S. Likelihood-Based Inference in Cointegrated Vector Autoregressive Models; Oxford University Press: New York, NY, USA, 1995.

93. MacKinnon, J.G.; Alfred, A.H.; Leo, M. Numerical distribution functions of likelihood ratio tests for cointegration. J. Appl. Econom. 1999, 14, 563-577. [CrossRef]

94. Juselius, K. The Cointegrated VAR Model: Methodology and Applications; Oxford University Press: Oxford, UK, 2006.

95. Hendry, D.F.; Ericsson, N.R. Understanding Economic Forecasts; MIT Press: Cambridge, MA, USA, 2001.

96. Allen, P.G.; Fildes, R.A. Econometric forecasting strategies and techniques. In Principles of Forecasting: A Handbook for Researchers and Practitioners; Armstrong, J.S., Ed.; Kluwer Academic Press: Dordrecht, The Netherlands, 2001.

97. Diebold, F.X. Elements of Forecasting; South-Western College Publishing: Cincinnati, OH, USA, 1988.

98. Granger, C.J.; Newbold, P. Forecasting Economic Time Series, 2nd ed.; Academic Press: New York, NY, USA, 1986.

99. Clements, M.P.; Hendry, D.F. Forecasting Non-Stationary Time Series; MIT Press: Cambridge, MA, USA, 1999.

100. Clements, M.P.; Hendry, D.F. Economic forecasting in a changing world. Capital. Soc. 2008, 3, 1-18. [CrossRef]

101. Fakulta Hospodarskej Informatiky. Available online: http://www.fhi.sk/files/katedry/kove/predmety/ Prognosticke_modely/Methods_basics.pdf (accessed on 26 September 2016).

102. Engle, R.F.; Yoo, B.S. Forecasting and testing in co-integrated systems. J. Econom. 1987, 35, 143-159. [CrossRef]

103. Clements, M.P.; Hendry, D.F. Forecasting in cointegrated systems. J. Appl. Econom. 1995, 10, 127-146. [CrossRef]

104. Armstrong, J.S. Principles of Forecasting: A Handbook for Researchers and Practitioners; Springer Science \& Business Media, Business \& Economics: Berlin, Germany, 2001; p. 849.

105. Azerbaijan 2020: Look into the Future Concept. Available online: http://www.president.az/files/future_en. pdf (accessed on 24 July 2016).

106. International Monetary Fund. IMF World Economic Outlook; IMF: Washington, DC, USA, 2013.

107. International Monetary Fund. Available online: http://www.imf.org/external/np/sec/pr/2016/pr16260. htm (accessed on 26 September 2016).

108. World Bank. Available online: http://www-wds.worldbank.org/external/default/WDSContentServer/ WDSP/IB/2015/07/21/090224b083014397/2_0/Rendered/PDF/Azerbaijan000C0the0period0FY2016020. pdf (accessed on 26 September 2016).

109. United Nations. Department of Economic and Social Affairs. Population Division. World Population Prospects, the 2015 Revision. 2016. Available online: https:/ / esa.un.org/unpd/wpp/Download/Standard/ Population/ (accessed on 24 July 2016).

110. Hasanov, F.; Hasanli, K. Why had the Money Market Approach been irrelevant in explaining inflation in Azerbaijan during the rapid economic growth period. Middle East. Financ. Econ. 2011, 10, 1-11.

111. Fitch. Fitch Ratings. 2016. Available online: http://azeri.press/iqtisadayyat/253557-fitch-azerbaycandainflyasiya-proqnozunu-yaxslasdrd--yenilenib.html (accessed on 24 July 2016).

112. Asian Development Bank. Asian Development Bank Outlook 2016. Asian's Potential Growth. 2016. Available online: http:/ /www.adb.org/sites/default/files/publication/182221/ado2016.pdf (accessed on 24 July 2016). 
113. The World Bank. Economic Update: Impact of China on Europe and Central Asia. Available online: http://www-wds.worldbank.org/external/default/WDSContentServer/WDSP/IB/2016/05/ 03/090224b0842f1054/3_0/Rendered/PDF/The0impact0of00ope0and0Central0Asia.pdf (accessed on 26 September 2016).

114. IMF. World Economic Outlook (WEO). Too Slow for Too Long. Available online: http://www.imf.org/ external/pubs/ft/weo/2016/01/pdf/tblparta.pdf (accessed on 26 September 2016).

(C) 2016 by the authors; licensee MDPI, Basel, Switzerland. This article is an open access article distributed under the terms and conditions of the Creative Commons Attribution (CC-BY) license (http://creativecommons.org/licenses/by/4.0/). 